\title{
PRVA IN DRUGA IZDAJA SSKJ
}

\section{Simon KREK}

Institut "Jožef Stefan", Laboratorij za umetno inteligenco

Univerza v Ljubljani, Filozofska fakulteta

Krek, S. (2014): Prva in druga izdaja SSKJ. Slovenščina 2.o, 2 (2): 114-16o.

URL: http://www.trojina.org/slovenscina2.o/arhiv/2014/2/Slo2.o_2014_2_o8.pdf.

V prispevku obravnavamo razlike med prvo in drugo izdajo Slovarja slovenskega knjižnega jezika. Analiza obsega dva ločena postopka: detajlno primerjavo celotnega geslovnika obeh slovarjev in analizo 2.500 geselskih člankov iz obeh slovarjev, po sto iz vsake črke. Analiza kaže, da je v drugi izdaji SSKJ vsebovan poseg $\mathrm{v}$ pravopisno in pravorečno podobo slovenščine brez razvidnega mandata za ta poseg, da so spremembe naključne in nekonsistentne, pri čemer je poleg razrušenja konsistentnega slovarskega opisa iz prve izdaje vprašljiv predvsem poseg v slovnični opis slovenskega jezika, vsebovan v drugi izdaji, in da zaradi redakcijske odločitve, da se popolnoma zabriše možnost razločevanja, ali slovarski podatki izhajajo iz prve izdaje ali iz Slovarja novejšega besedja slovenskega jezika, druga izdaja prinaša strokovno vprašljiv slovarski opis sodobnega slovenskega jezika. S strokovnega, leksikografskega stališča bi bilo primerneje, če bi prva izdaja ostala nespremenjena, s Slovarjem novejšega besedja slovenskega jezika kot svojo ločeno publikacijo. Poleg tega druga izdaja ni prosto dostopna na spletu, nobena od izdaj pa ni prosto dostopna kot slovarska baza v računalniško procesljivem formatu.

Ključne besede: Slovar slovenskega knjižnega jezika, Slovar novejšega besedja slovenskega jezika, Slovenski pravopis

\section{UVOD}

Tema prispevka je detajlna primerjava razlik med prvo in drugo izdajo Slovarja slovenskega knjižnega jezika. ${ }^{1}$ Pri analizi poleg obeh izdaj upoštevamo tudi

\footnotetext{
${ }^{1}$ Reference vseh slovarskih del in portalov so navedene v bibliografiji. V nadaljevanju s kratico
} 
povezana dela: slovarski del Slovenskega pravopisa (Toporišič idr. 2001) ter Slovar novejšega besedja slovenskega jezika (Bizjak Končar idr. 2013). Vsako od predhodnih treh povezanih del (SSKJ1, SP2001, SNB) je bilo zasnovano s svojim lastnim konceptom. SSKJ1 je začel nastajati v šestdesetih letih iz češkega modela s konceptom »knjižnega jezika«, izhajajoč iz načrtno zbranega listkovnega gradiva. Njegova zasnova je bila javno preverjena po objavi Poskusnega snopiča (Bajec idr. 1964). SP2001 ni več nastal na sistematično zbranem novem gradivu (Gorjanc 2001), za gradivsko osnovo je bil izbran SSKJ1 (Dobrovoljc idr. 2011), je pa $\mathrm{v}$ okviru mandata in pod vodstvom predsednika Komisije za sestavo slovarskega dela novega slovenskega pravopisa Jožeta Toporišiča uvedel precej slovničnih, pravopisnih in pravorečnih rešitev, ki niso (bile) združljive s tistimi v SSKJ1. Predsednik komisije je svoje (slovnične) rešitve pravzaprav uveljavljal kot kritiko tistih iz SSKJ, a vendar v okviru javno predstavljenega koncepta (Toporišič 1994), ki je bil podprt z uradno imenovano komisijo. Na tretji strani SNB konceptualno ni nastal z ambicijo nadaljnjega uveljavljanja koncepta »knjižnosti«, ki so se mu avtorji zavestno izognili, in to $\mathrm{z}$ dobrim razlogom, saj je v njem besedišče, ki v prvotni SSKJ1 v nobenem primeru ne bi bilo sprejeto. ${ }^{2}$ Kljub temu je skoraj celoten SNB na koncu pristal v drugi izdaji SSKJ, s čimer je pravzaprav razgrajen pojem »knjižnega jezika« iz prve izdaje SSKJ.

V tem smislu lahko le ponovimo kritično ugotovitev nekaterih avtorjev prve izdaje SSKJ iz recenzije druge izdaje:

Čemu bi si prizadevali za slovaropisno strokovnost (in se iz strokovnih ozirov odpovedali prenovitvenemu poslu, ki je s slovaropisnega stališča vprašljiv in $\mathrm{v}$

SSKJ1 označujemo prvo izdajo, s SSKJ2 pa drugo izdajo Slovarja slovenskega knjižnega jezika. Za slovarski del Slovenskega pravopisa uporabljamo kratico SP2001, za Slovar novejšega besedja slovenskega jezika pa kratico SNB.

${ }^{2}$ Avtorji SNB so svoje delo tudi eksplicitno utemeljili z odmikom od namena kultivacije jezika: »Namembnost in učinkovitost jezikovnega izraza vedno bolj izpodriva kulturne zahteve, rahlja jezikovne norme in vpliva na njegovo pretočnost. Zato so za novejše besedje značilne jezikovne lastnosti, ki so velikokrat v neskladju s predpisi o standardizaciji in kultivaciji jezika (SNB 2013: 11). 
rezultatu jezikovnokulturno zavajajoč), če pod okriljem avtoritete najvišje znanstvene ustanove, varni pred posledicami morebitne strokovne kritike, zlahka prodajajo kar koli, tudi zastareli slovar s slovesom novega (Ahlin idr. 2014: 127).

V nadaljevanju opišemo dve vsebinsko in postopkovno ločeni analizi. Prva je analiza geslovnika SSKJ2 in njegova primerjava z geslovniki SSKJ1, SNB in SP2001. V drugi analizi primerjamo vsebino geselskih člankov v SSKJ1 in SSKJ2. Vsi spiski, primerjave in dokumenti so na voljo kot del prispevka. ${ }^{3}$

\section{GESLOVNIK}

Vprašanje, kako primerjati slovarske geslovnike, je bilo vedno problematično, tako v tiskanem kot digitalnem mediju, kajti slovarji so precej različno notranje strukturirani. V zaglavjih se pogosto pojavljajo dvojnice ali variantne oblike, ki imajo podoben status kot iztočnica, zelo raznolika je tudi obravnava različnih vrst podiztočnic (Landau 2004: 98-105). V nadaljevanju izvajamo primerjavo geslovnikov z izhodiščem $\mathrm{v}$ spiskih, ki so del prispevka, torej je vse ugotovitve mogoče preveriti. Pri tem je treba upoštevati, da ti spiski niso v celoti identični s slovarsko strukturo, ki je dostopna sodelavcem Inštituta za slovenski jezik, saj nobeden od analiziranih slovarjev ni javno dostopen tudi kot slovarska baza. Po sugestiji predstojnika Inštituta za slovenski jezik Frana Ramovša so bili za primerjavo uporabljeni podatki, kakršni so na voljo v formatu HTML na portalu Fran, ${ }^{4}$ pretvorjeni v lažje procesljivo obliko. Podatki so podani v Tabeli 1.

Zanimajo nas štirje geslovniki: SSKJ1, SP2001, SNB in SSKJ2 (po kronološkem

\footnotetext{
3 Dostopno prek:

http://www.trojina.org/slovenscina2.o/arhiv/2014/2/Spiski/SSKJ1-2_geslovnik_osnovni_prim.zip http://www.trojina.org/slovenscina2.o/arhiv/2014/2/Spiski/SSKJ1_geslovnik_osnovni.zip http://www.trojina.org/slovenscina2.o/arhiv/2014/2/Spiski/SSKJ1_geslovnik_osnovni_norm.zip http://www.trojina.org/slovenscina2.o/arhiv/2014/2/Spiski/SSKJ2_geslovnik_osnovni.zip http://www.trojina.org/slovenscina2.o/arhiv/2014/2/Spiski/SSKJ2_geslovnik_osnovni_norm.zip http://www.trojina.org/slovenscina2.o/arhiv/2014/2/Spiski/SNB_geslovnik_Izt_Dvoj_Pod.zip http://www.trojina.org/slovenscina2.o/arhiv/2014/2/Spiski/SNB_geslovnik.zip http://www.trojina.org/slovenscina2.o/arhiv/2014/2/Spiski/SP2001_v1_geslovnik_iztocnica.zip http://www.trojina.org/slovenscina2.o/arhiv/2014/2/Spiski/SP2001_v1_iztocnica_podiztocnica\%28m ala\%29.zip

4 Spletna stran: http://www.fran.si.
} 
redu). Po štetju v naši obravnavi osnovni geslovnik SSKJ1 obsega 93.154 iztočnic, SSKJ2 97.669. SP2001 ima na portalu Fran navedenih 92.615 iztočnic, v priloženem spisku je ena manj. Pri SP2001 je treba upoštevati tudi to, da vsebuje veliko število podiztočnic, zato je $\mathrm{v}$ nekaterih primerih bolj smiselno primerjati seštevek iztočnic in različnih tipov podiztočnic, ki jih je skupaj 140.264. SNB vsebuje 5.382 iztočnic. Primerjavo SNB s SSKJ1 oz. SSKJ2 nekoliko zaplete to, da so nekatere od iztočnic v SNB že vsebovane v omenjenih slovarjih. Razširjeni spisek SNB obsega 6.583 iztočnic. 5

\begin{tabular}{l|rr}
\hline Slovar & Osnovni geslovnik & Razširjeni spiski \\
\hline SSKJ1 & 93.154 & \\
\hline SSKJ2 & 97.669 & \\
\hline SP2O01 & 92.614 & 140.264 \\
\hline SNB & 5.382 & 6.583 \\
\hline
\end{tabular}

Tabela 1: Število iztočnic v SSKJ1, SSKJ2, SP2001 in SNB.

\subsection{Izločene iztočnice 6}

Kot navajajo tudi avtorji SSKJ2 (Gliha Komac idr. 2014), je bilo v slovarju iz geslovnika SSKJ1 odstranjenih šest iztočnic zaradi zahteve imetnikov blagovnih znamk po zapisu iztočnice $\mathrm{z}$ veliko začetnico in simbolom za registrirano blagovno znamko $\circledR$ : cockta/kokta, superga, teflon, teflonski in tetrapak. Geselski članki s temi iztočnicami so bili naknadno objavljeni v reviji Jezikoslovni zapiski (ibid.).

Na ravni osnovnega geslovnika se razlika med SSKJ1 in SSKJ2 pojavlja pri nadaljnjih 67 iztočnicah. To ne pomeni, da so bili izločeni tudi geselski članki, ki vsebujejo te iztočnice, temveč so bile lahko preurejene informacije znotraj

5 Glede na vsebino datotek v HTML formatu pri SP2001 upoštevamo kategorije Iztočnica, Podiztočnica in Mala podiztočnica, pri SNB pa Iztočnica, Podiztočnica in Dvojnica.

${ }^{6}$ Spisek izločenih iztočnic dostopen prek:

http://www.trojina.org/slovenscina2.o/arhiv/2014/2/Spiski/SSKJ1-

2_geslovnik_osnovni_prim_izloceno_iz_SSKJ1.zip. 
njih. Razlogi za umanjkanje teh iztočnic v osnovnem geslovniku SSKJ2 so različni. Nekateri geselski članki so bili združeni s svojimi homonimnimi pari: ali, cent, forum, inštruirati, sodelavec in sesúvati se (pod sesúvati). Na primer: članek z iztočnico àli, ki je bila v SSKJ1 opredeljena kot prislov v medmetni rabi, se je v SSKJ2 pridružil geselskemu članku, ki vsebuje členek.7

$\mathrm{V}$ drugih primerih so geselski članki ostali v slovarju, vendar z dvojnicami, ki so postale iztočnice, same iztočnice iz SSKJ1 pa so bile dejansko izbrisane: blufer (blefer), blufirati (blefirati), debutánt (debitánt), debutántka (debitántka), debutántski (debitántski), Jehovin (Jehovov), Morsov in Morzejev (Morsejev).

Pri preostalih iztočnicah, kjer se na ravni osnovnega geslovnika pojavlja razlika med SSKJ1 in SSKJ2, gre za zamenjavo iztočnice in dvojnice v SSKJ1 in SSKJ2, torej iztočnice niso bile izbrisane, tako kot v zgornjih primerih. Po kategorijah jih lahko razporedimo v nekaj skupin (v oklepaju so iztočnice iz SSKJ2):

1. (pol)citatni-podomačen zapis: avtocamping (ávtokámping), bohéma (boéma), bohémski (boémski), bohémstvo (boémstvo), camping (kámping), caraváning (karaváning), chartístičen (čartístičen), chartízem (čartízem), cioníst (sioníst), cionístičen (sionístičen), cócktailski (kóktajlski), dumpinški (dámpinški), gríll (gríl), handicapírati (hendikepírati), knockoutírati (nokavtírati), management (mênedžment), managerski (mênedžerski, managerstvo (mênedžerski), punkovski (pánkovski), rugbyjíst (ragbíst), teenagerski (tínêjdžerski), tezávrus (tezáver);

2. zev: amóniakov (amónijakov), bastión (bastijón), divizión (divizijón), divizionár (divizijonár), gladióla (gladijóla) itd.;

3. soglasniška skupina st/št: ávtostópar (ávtoštópar), ávtostóparka (ávtoštóparka), instruíranje (inštruíranje), instruírati (inštruírati), instruktáža (inštruktáža), stópanje (štópanje), stópar (štópar), stóparka (štóparka);

4. podomačenje s/z: bísmutov (bízmutov), konsumácija, konsumacíjski, 
konsúmar, konsúmen, konsument, konsumentski, konsumíranje, konsumírati, konsúmpcija, konsumpcíjski, kvíslingovec, kvíslinški, masohístičen, masohízem, sadomasohízem;

Pod to rubriko navajamo tudi nekatere iztočnice, ki so pri analizi padle v kategorijo spremenjenih iztočnic, torej tistih, ki jih obravnavamo v naslednjem poglavju, vendar jih je po analogiji s prej navedenimi skupinami smiselno navesti skupaj. Gre za več skupin:

(a) menjava velike in male začetnice ali zapisa $\mathrm{z}$ velikimi/malimi črkami: Abraham, antarktika, arktika, božiček, Evstahijev, Francisov, Glauberjev, nep, Pirov, Priolov, ptt, pvc, RO-Ro, rtv, tbc;8

(b) zev: akia, aziat, aziatski, aziatstvo, balkaniada, danunciada, donkihotiada, jeremiada, kitariada, kristianija, meridian, meridianski, spartakiada, univerziada, valeriana;

(c) glagolski morfem se/si: abstinirati se, drzniti se, izmisliti se, izmišljati se, izmišljevati se, lastiti se, omisliti se, omišljati se, opomoči se, prilastiti se, prilastovati se, prilaščati se, primisliti se, prisvajati se, prisvojiti se, svojiti se, umisliti se, umišljati se, utvarjati se, zamisliti se, zamišljati se, zapominjati se, zapomniti se, zapomnjevati se, zmisliti se.

Pri tej zadnji skupini je bil v SSKJ2 zamenjan ali dodan morfem si, npr. izmisliti se $\rightarrow$ izmisliti si.

\subsection{Spremenjene iztočnice}

Na ravni osnovnega geslovnika je bilo med obema izdajama spremenjenih 2.561 iztočnic. ${ }^{9}$ Velika večina teh sprememb (2.497) izhaja iz razlike pri informacijah

\footnotetext{
${ }^{8} \mathrm{O}$ pravopisni problematiki velike in male začetnice več v poglavju 3.5 Pravopis.

9 Dostopno prek:

http://www.trojina.org/slovenscina2.o/arhiv/2014/2/Spiski/SSKJ1-

2_geslovnik_osnovni_prim_spremenjeno_v_SSKJ2.zip in

http://www.trojina.org/slovenscina2.o/arhiv/2014/2/Spiski/SSKJ1-

2_geslovnik_osnovni_prim_spremenjeno_v_SSKJ2_norm.zip.
} 
o naglasu, pri čemer gre pretežno za prenos nove interpretacije izgovorne podobe iz SP2001 v nekaj kategorijah. Kategoriji 2.2.1 in 2.2.2 izhajata iz večje spremembe med SSKJ1 in SP2001, ki jo avtorji v uvodu opišejo: "v glasoslovju je večja sprememba $\mathrm{v}$ rabi naglasnih znamenj na $e$ pred $j$ in na $o$ pred $v^{\prime \prime}$ (Toporišič idr. 2001, VI). Poglejmo nekaj primerov, ki jih navajamo naključno.

\subsubsection{OZKI E $\rightarrow$ ŠIROKI E}

\begin{tabular}{l|l|l}
\hline SSKJ1 & SSKJ2 & SP2oo1 \\
\hline afežéjevka & afežêjevka & afežêjevka \\
\hline baziléj & bazilêj & bazilêj \\
\hline čarodéj & čarodêj & čarodêj \\
\hline déjstvo & dêjstvo & dêjstvo \\
\hline egéjski & egêjski & egêjski \\
\hline farizéj & farizêj & farizêj \\
\hline galéja & galêja & galêja \\
\hline hebréjščina & hebrêjščina & hebrêjščina \\
\hline idéja & idêja & idêja \\
\hline jubiléj & jubilêj & jubilêj \\
\hline kaldéjski & kaldêjski & kaldêjski \\
\hline licéjka & licêjka & licêjka \\
\hline manihéjec & manihêjec & manihêjec \\
\hline nadéjati se & nadêjati se & nadêjati se \\
\hline
\end{tabular}

2.2.2 OZKI O $\rightarrow$ ŠIROKI O

\begin{tabular}{l|l|l}
\hline SSKJ1 & SSKJ2 & SP2oo1 \\
\hline algóvnica & algôvnica & algôvnica \\
\hline bajeslóvje & bajeslôvje & bajeslôvje \\
\hline dimolóvec & dimolôvec & dimolôvec \\
\hline fižólčkati & fižôlčkati & fižôlčkati \\
\hline hlodóvje & hlodôvje & hlodôvje \\
\hline
\end{tabular}




\begin{tabular}{l|l|l}
\hline iztólči & iztôlči & iztôlči \\
\hline kakóvosten & kakôvosten & kakôvosten \\
\hline mesóvje & mesôvje & mesôvje \\
\hline plodóvje & plodôvje & plodôvje \\
\hline slóvstvo & slôvstvo & slôvstvo \\
\hline trgóvec & trgôvec & trgôvec \\
\hline valóvje & valôvje & valôvje \\
\hline žólca & žôlca & žôlca \\
\hline
\end{tabular}

2.2.3 PREMIK NAGLASNEGA MESTA

\begin{tabular}{l|l|l}
\hline SSKJ1 & SSKJ2 & SP2oo1 \\
\hline áerodinámičen & aêrodinámičen & aêrodinámičen \\
\hline bátik & batík & batík \\
\hline decémvir & decemvír & decemvír \\
\hline ému & emú & emú \\
\hline éskimski & eskímski & eskímski \\
\hline kábala & kabála & kabála \\
\hline kompásen & kómpasen & kómpasen \\
\hline olimpioník & olimpiónik & olimpiónik \\
\hline rodéo & ródeo & ródeo \\
\hline topníški & tópniški & tópniški \\
\hline vnémar & vnemár & vnemár \\
\hline
\end{tabular}

\subsubsection{ODVZETO NAGLASNO MESTO}

Pri iztočnicah, ki se pojavljajo tako v SSKJ1 kot v SSKJ2, a v SSKJ2 nimajo označenega naglasnega mesta na iztočnici, temveč $\mathrm{v}$ zaglavju $\mathrm{v}$ oglatem oklepaju, gre večinoma za citatno ali polcitatno prevzete besede, pri katerih je bilo treba v SSKJ1 (ali SP2001) za ustrezno interpretacijo izgovora za del iztočnice ali celotno iztočnico izpisati tudi fonetično transkripcijo. V SSKJ2 so bili vsi okrajšani zapisi iz SSKJ1 in SP2001 pretvorjeni v zapis izgovora celotne 
iztočnice, npr. arpéggio [-edžo] $\rightarrow$ [arpédžo]. V teh primerih je bil torej podatek o naglasnem mestu v SSKJ2 večinoma prenesen z iztočnice v zapis izgovora.

\begin{tabular}{l|l|l}
\hline SSKJ1 & SSKJ2 & SP2oo1 \\
\hline accelerándo & accelerando & accelerándo \\
\hline báselski & baselski & báselski \\
\hline chêrry & cherry & chêrry \\
\hline chiánti & chianti & chiánti \\
\hline de iúre & de iure & de iúre \\
\hline écce hómo & ecce homo & écce hómo \\
\hline fait accomplí & fait accompli & fait accomplí \\
\hline glissándo & glissando & glissándo \\
\hline jóhnson & johnson & jóhnson \\
\hline kníttelvêrz & knittelverz & kníttelvêrz \\
\hline montagnárd & montagnard & montagnárd \\
\hline pórsche & porsche & pórsche \\
\hline
\end{tabular}

\subsubsection{DODANO NAGLASNO MESTO}

Opazujemo lahko tudi obratni proces. Ta poseg je sicer manj razumljiv od zgoraj opisanega prenosa zapisa naglasnega mesta v zaglavje, saj ta dejansko pripomore k ločevanju citatnih naglasnih znamenj (npr. abbé) od slovarskega označevanja naglasa znotraj iztočnice. V omenjenih primerih torej naglasnega mesta v iztočnici SSKJ1 ni, bilo pa je dodano tako v SP2001 in tudi v SSKJ2. Logika dodajanja v SSKJ2 sicer ni povsem jasna, ker v SP2001 posebnega zapisa izgovora v zaglavju ni, torej je dodajanje naglasa logično, v SSKJ1 (in torej tudi SSKJ2) pa ta že obstaja, zato je informacija o naglasu podvojena, npr.:

- SSKJ1: agrema -ja in agrement -a [-má -ja]

- SP2001: agremá -ja

- SSKJ2: agremá -ja in agrement -a [agremá -ja]. 


\begin{tabular}{l|l|l}
\hline SSKJ1 & SSKJ2 & SP2oo1 \\
\hline agrema & agremá & agremá \\
\hline angstrem & ángstrem & ángstrem \\
\hline biftek & bíftek & bíftek \\
\hline dizel & dízel & dízel \\
\hline grež & gréž & gréž \\
\hline hardver & hárdvêr & hárdvêr \\
\hline luping & lúping & lúping \\
\hline skvo & skvó & skvó \\
\hline šov & šôv & šôv \\
\hline valer & valêr & valêr \\
\hline žur & žúr & žúr \\
\hline
\end{tabular}

\subsubsection{ANALOGIJA BREZ SP2O01}

Naslednja kategorija sprememb med SSKJ1 in SSKJ2 zajema primere, pri katerih iztočnica (oz. geselski članek) ni prišla iz SSKJ1 v SP2001, prišlo pa je do sprememb med obema izdajama SSKJ. Pri navedenih iztočnicah je mogoče narediti analogijo s sistemskimi spremembami v paru SSKJ1-SP2001, čeprav samih iztočnic torej v SP2001 ni.

\begin{tabular}{l|l|c}
\hline SSKJ1 & SSKJ2 & SP2001 \\
\hline akóv & akôv & - \\
\hline bezgóvje & bezgôvje & - \\
\hline blagoslóven & blagoslôven & - \\
\hline daróvnica & darôvnica & - \\
\hline hanóvrski & hanôvrski & - \\
\hline komólček & komôlček & - \\
\hline opólzel & opôlzel & - \\
\hline
\end{tabular}




\begin{tabular}{l|l|c}
\hline SSKJ1 & SSKJ2 & SP2oo1 \\
\hline avgustéjski & avgustêjski & - \\
\hline daréjek & darêjek & - \\
\hline franciscéjski & franciscêjski & - \\
\hline izcéja & izcêja & - \\
\hline jéjtana & jêjtana & - \\
\hline podréjanje & podrêjanje & - \\
\hline spiréja & spirêja & - \\
\hline
\end{tabular}

\subsubsection{SSKJ2 V NASPROTJU S SP2O01}

Od tu naprej spremembe geslovnika v SSKJ2 glede na SSKJ1 in v primerjavi s SP2001 (ki se v tem delu sicer skoraj v celoti nanašajo na podatke o naglasu) postanejo zanimivejše. Te na ravni koncepta nikjer niso opisane, razen $\mathbf{s}$ splošnimi opredelitvami tipa »Posodobitve posameznih prvin slovarskih sestavkov so bile sistematično izpeljane predvsem tam, kjer to zahteva duh časa, vendar le v omejenem obsegu « (SSKJ2 2014: 7). Neobstoj koncepta oz. nejasnosti glede sprememb kritizirajo tudi avtorji SSKJ1:

Glede na obsežnost in pomembnost SSKJ bi se pričakovalo tudi, da bi priprava druge izdaje vključevala recenzijski postopek ali temu ustrezno strokovno presojo, pri kateri bi bil slovaropisno in uporabnostno ocenjen koncept prenovitve in izvedba; to bi se pričakovalo še zlasti zato, ker nihče iz skupine prenoviteljev nima uredniških izkušenj z delom pri temeljnem splošnem slovarju, pač pa zgolj pri Slovarju novejšega besedja, ki se po zahtevnosti ne more primerjati s SSKJ. Prav tako bi se pričakovalo, da bi pripravo druge izdaje vodil uredniški odbor, ki bi nosil odgovornost za opravljene spremembe; to, da so v prenovitveni skupini navedeni vsi sodelavci kot enakovredni /.../, vzbuja nezaupanje glede odgovornosti tistih z najvišjimi znanstvenimi nazivi (Ahlin idr. 2014: 121).

Najprej se za torej za hip spomnimo, na kakšen način je bila odgovornost za vsebino obravnavana v SSKJ1 in SP2001. Vsaka od petih knjig SSKJ je imela svoj "glavni uredniški odbor «, poleg tega tudi različne komisije. V prvi knjigi SSKJ1 je tako navedeno: 
$\mathrm{A}-\mathrm{H}$

Za pravopis: glavni uredniški odbor in dr. Jakob RIGLER, znanstv. svetnik

Za pravorečje in oblikoslovje: dr. Jakob RIGLER s sodelovanjem dr. Antona BAJCA, Staneta SUHADOLNIKA in dr. Franceta TOMŠIČA (začetna dela za pravopis in pravorečje je vodil dr. Jože TOPORIŠIČ, doc.)

Za tonemskost: dr. Jakob RIGLER s sodelovanjem dr. Antona BAJCA, dr. Tineta LOGARJA, univ. prof., in Staneta SUHADOLNIKA (SSKJ 2014, 10)

In podobno naprej pri preostalih knjigah prve izdaje. Pri SP2001 je bilo delo formalno $\mathrm{v}$ rokah Komisije za sestavo slovarskega dela novega slovenskega pravopisa, o kateri je v uvodu v pravopis (SP 2001, VII) navedeno:

To komisijo je imenoval predsednik SAZU J. Milčinski spomladi 1990. Konstituirala se je kot uredniški odbor: njegov predsednik je postal J. Toporišič, kot člani pa so v njej delovali: J. Dular (razen od 11. 9. 1990 do 19. 5. 1992 in od 6. 2. 1996 do 8. 4. 1997), V. Gjurin (do 24. 9. 1991), F. Jakopin (do 21. 12. 1993), J. Moder (do 29. 11. 1994), B. Pogorelec (do 24. 9. 1991), A. Vidovič Muha (do 24. 9. 1991); 21. 2. 1995 je z dekretom predsednika SAZU F. Bernika postala članica uredniškega odbora M. Hajnšek - Holz.

Če povzamemo: za pravopisnimi, pravorečnimi in drugimi rešitvami v SSKJ1 in SP2001 so za razliko od SSKJ2 »stali« bolj ali manj jasno razvidni organi, ki jih je potrjevala SAZU. V tej luči so torej zanimive tiste (pravopisne in pravorečne) spremembe v SSKJ2, ki jih ni mogoče najti v delih ali izpeljati iz del, ki so take organe imeli, torej v SSKJ1 in v SP2001.

Pri branju spiskov iz tabel v nadaljevanju se je treba zavedati, da odgovornost za spremembe v naglasni podobi iztočnic v skladu s sugestijo avtorjev SSKJ1 lahko pripišemo avtorjem »z najvišjimi znanstvenimi nazivi« med avtorji SSKJ2, to sta torej znanstveni svétnik dr. Marko Snoj in znanstvena svétnica dr. Andreja Žele. V nobenem primeru pa ne vemo, na kakšni (strokovni) podlagi se je kolektivni avtorski organ za vsako posamično spremembo odločil, saj konceptualno nikjer niso bile pojasnjene.

$\mathrm{V}$ navedenih primerih gre večinoma za zamenjavo osnovne iztočnice in 
variantne oblike ali za dodajanje osnovne iztočnice in prekvalifikacijo iztočnice iz SSKJ1 v variantno obliko. A vendar, kar je navedeno v stolpcu SSKJ2, je torej nova osnovna iztočnica $v$ geselskem članku.

\begin{tabular}{l|l|l}
\hline SSKJ1 & SSKJa & SP2oo1 \\
\hline alínea & alinêa & alínea \\
\hline anéks & áneks & anéks \\
\hline apostólski & apostôlski & apostólski \\
\hline ápsida & apsída & ápsida \\
\hline arhivólta & arhivôlta & arhivólta \\
\hline bogomólka & bogomôlka & bogomólka \\
\hline brátranček & bratránček & brátranček \\
\hline čoháti & čóhati & čoháti \\
\hline démon & demón & démon \\
\hline dohódkoven & dohodkôven & dohódkoven \\
\hline doktrinár & doktrínar & doktrinár \\
\hline eólski & eôlski & eólski \\
\hline gráfikon & grafikón & gráfikon \\
\hline híndu & hindú & híndu \\
\hline jébati & jêbati & jébati \\
\hline kemíjski & kémijski & kemíjski \\
\hline kozíca & kôzica & kozíca \\
\hline leopárd & lêopard & leopárd \\
\hline maratónec & máratonec & maratónec \\
\hline naslóvljenec & naslôvljenec & naslovljênec \\
\hline páčuli & pačúli & páčuli \\
\hline pešadíja & pešádija & pešadíja \\
\hline repôrter & repórter & repôrter \\
\hline tándem & tandém & tándem \\
\hline záplata & zapláta & záplata \\
\hline & & \\
\hline
\end{tabular}


Prav tako pa v SSKJ2 lahko opazujemo tudi obratno situacijo, pri kateri sta bila iztočnica oz. naglas v SP2001 glede na SSKJ1 spremenjena, v drugi izdaji SSKJ pa se iz predala kot preferenčna vrača prvotna varianta.

\begin{tabular}{l|l|l}
\hline SSKJ1 & SSKJa & SP2oo1 \\
\hline akróstih & akróstih & akrostíh \\
\hline buldožêr & buldožêr & búldožer \\
\hline celíti & celíti & céliti \\
\hline črtomírstvo & črtomírstvo & čŕtomirstvo \\
\hline dvorján & dvorján & dvorjàn \\
\hline elefantíaza & elefantíaza & elefantiáza \\
\hline émir & émir & emír \\
\hline esêr & esêr & éser \\
\hline fižòl & fižòl & fižôl \\
\hline gurú & gurú & gúru \\
\hline ínfinitiv & ínfinitiv & infinitív \\
\hline jezerján & jezerján & jezerjàn \\
\hline kanábis & kanábis & kánabis \\
\hline knjižéven & knjižéven & knjíževen \\
\hline
\end{tabular}

Omeniti velja vsaj še par iztočnic s presenetljivimi pravorečnimi rešitvami. Taka primera sta alkohôlnat in alkohôlski, ki sta v SSKJ2 pridobila široki o. V SSKJ1 sta navedena z ozkim o, SP2001 teh gesel nima. Velja tudi opozoriti, da so bile spremembe, pri katerih je šlo za zamenjavo naglasne informacije po celotnem slovarju, uvedene tudi pri iztočnicah, ki so kvalificirane z »zastarelo « (skólke : skôlke - 'mrtvaški oder') ali »narečno« (stólnica : stôlnica - 'prt'), kar tovrstne intervencije postavlja pod vprašaj.

Bistvo pa je naslednje: pri navedenih in ostalih primerih ne gre za vprašanje, ali 
sta podatka o naglasu ali naglasnem mestu iz SSKJ2 »pravilnejša« ali ne. Gre za to, kdo pravzaprav stoji za nikjer pojasnjenimi odločitvami, ki so v verigi SSKJ1-SP2001-SSKJ2 kronološko zadnje, in kakšni so argumenti odločevalcev, zaradi katerih bodo - predvidevamo - rdeče svinčnike pospravili ali spravili na plano učitelji slovenščine $\mathrm{v}$ šolah in po čem se bodo ravnali lektorji, spikerji na radiu itd. Če je v SSKJ2 ponovno vzpostavljen naglas iz SSKJ1, vmes pa je neko drugo pravorečno telo v okviru SP2001 sprejelo drugačno odločitev, je odločitev tega telesa s tem ukinjena. Ali kako? Če slovar ni normativen v razmerju do SP2001, ker je »zgolj informativno-normativen, « potem ima še manj smisla, da je nastal in je zavajajoč. Če pa naj bi se nanj sklicevali kot na referenčno delo, nihče ne ve, od kod rešitve.

\subsection{Dodane iztočnice (iz SNB in SP2001)}

Na priloženem spisku ${ }^{10}$ je 4.587 iztočnic, ki so bile dodane v SSKJ2. Od teh je 3.608 neposredno tudi v geslovniku SNB. Za nadaljnjo analizo jih ostane 979 in dodatno še 107 takih, ki v SNB sicer so, a se razlikujejo po naglasu. Od teh lahko pri 570 iztočnicah identificiramo razlike, ki jih je mogoče razporediti v nekaj kategorij.

(a) Daleč največji delež obsegajo pridevniki, ki so v SNB navedeni kot vrstni pridevniki oz. v določni obliki, v SSKJ2 pa so se vrnili v nedoločno obliko oz. je iztočnična oblika kakovostni pridevnik: ávrični (ávričen), ávtoalármni (ávtoalármen), ávtocéstni (ávtocésten), avtológni (avtológen), avtomobilístični (avtomobilístičen), azbéstcementni (azbéstcementen), azílni (azílen), bájtni (bájten), bankomátni (bankomáten), besediloslôvni (besediloslôven), bíoaktívni (bíoaktíven), flambírani (flambíran), izštékani (izštékan), nèatestírani (nèatestíran), nèavtorizírani (nèavtorizíran), nèdrséči (nèdrséč), nègazírani (nègazíran) itd.

\footnotetext{
10 Dostopno prek: http://www.trojina.org/slovenscina2.o/arhiv/2014/2/Spiski/SSKJ12_geslovnik_osnovni_prim_dodano_v_SSKJ2.zip in http://www.trojina.org/slovenscina2.o/arhiv/2014/2/Spiski/SSKJ1-

2_geslovnik_osnovni_prim_dodano_v_SSKJ2_norm.zip.
} 
(b) Razmeroma veliko skupino predstavljajo iztočnice, ki imajo v SNB naglasno znamenje, v SSKJ2 pa ne, večinoma zato, ker je pri teh v SSKJ2 le kazalka na drugo (ustreznejšo) iztočnico oz. geselski članek: domiada, džakuzi, džambo, fajl, falkon, feragosto, fidbek, getizacija, getizirati, gremi, grinpisovec, hardkor, hardrok, heliodrom, helioport, hepening, impičment itd.

(c) Nekatere iztočnice so na prehodu med SNB in SSKJ2 izgubile dvojni naglas in ohranile le primarnega: ánglomaníja (anglomaníja), egíptomaníja (egiptomaníja), égomaníja (egomaníja), évrofobíja (evrofobíja), héteroseksuálec (heteroseksuálec), hómoerótika (homoerótika), hómofobíja (homofobíja) itd.

(d) Pri nekaterih iztočnicah je bil naglas tudi zamenjan. Zanimiv primer je denimo iztočnica denacionalizácijski iz SNB, pri kateri je bil naglas v SSKJ2 prestavljen na denacionalizacíjski, čeprav obstaja tudi v SP2001 iztočnica z istim naglasom, kot ga ima SNB. Taki primeri so denimo še repopulácijski (repopulacíjski), simulacíjski (simulácijski) itd.

(e) Zadnjo skupino predstavljajo iztočnice, ki so v SNB navedene kot besedne zveze, v SSKJ2 je kot iztočnica sprejet del zveze, ta pa je v celoti navedena v geselskem članku: creutzfeldt-jakobova bolézen (Creutzfeldt-Jakobov), dezóksiribonukleínska kislína (dezóksiribonukleínski).

Ostane nam še 516 iztočnic, za katere lahko rečemo, da ne izhajajo neposredno iz SNB. Od teh daleč največjo skupino, skupaj polovico (259), sestavljajo tvorjenke, med njimi predvsem ženske oblike, kar pomeni, da je bila v večini primerov razlaga že na voljo iz moške oblike: aleksandrinka, biatlonka, evroposlanka, gostinka, grkokatoličanka, gurmanka, gurujka, intervjuvanka, krajanka, maratonka, navdušenka, osmoljenka, preiskovanka, šamanka, šavrinka, triatlonka, veganka, vegetarijanka, zasvojenka, zavezanka, cenilka, davkoplačevalka, dostavljalka, iskalka, kmetovalka, kršilka, lokostrelka, metalka, molilka, načrtovalka, onesnaževalka, opremljevalka, osnovnošolka, ostrostrelka, plenilka, pogajalka, ponavljalka, posnemovalka, pospeševalka, 
pospravljalka, požiralka, pravobranilka, pregledovalka, preiskovalka, spodbujevalka, sprejemalka, staroselka, tečka, upravljalka, valilka, volilka, zajedalka, zalezovalka, zapisovalka, zasledovalka, zmerjalka, konservativka, negativka, oskarjevka, tožljivka, vremenoslovka, zmerjavka, basistka, četrtfinalistka, debitantka, esejistka, folkloristka, galeristka, hokejistka, humoristka, judoistka, karateistka, karieristka, karikaturistka, kitaristka, klaviaturistka, koproducentka, kriminalistka, kronistka, lobistka, migrantka, motoristka, nudistka, oboistka, perfekcionistka, polfinalistka, praktikantka, producentka, projektantka, prokuristka, protikandidatka, vaterpolistka, veleslalomistka, violistka, violončelistka, vokalistka, žirantka, dobrodelnica, dolgoprogašica, enonaglasnica, estradnica, finančnica, folklornica, gospodarstvenica, investitorica, kantavtorica, kongresnica, korektorica, kosica, kršiteljica, mentorica, mirovnica, nečlanica, nogometašica, odpadnica, poddesetnica, podložnica, poročnica, pošiljateljica, potapljačica, prijaviteljica, pripornica, pritožnica, prorektorica, protestnica, utemeljiteljica, velemojstrica, vinogradnica, vlagateljica, zapustnica, zaslužkarica, zbirateljica, župnica, anesteziologinja, antropologinja, dramaturginja, enologinja, epidemiologinja, etnologinja, grafologinja, kardiologinja, klimatologinja, komunikologinja, mikrobiologinja, muzikologinja, nevrologinja, oftalmologinja, onkologinja, patologinja, podprvakinja, politologinja, stomatologinja, svatinja, svobodnjakinja, tehnologinja, zahodnjakinja, akterka, analitičarka, animatorka, aranžerka, avtoštoparka, balinarka, blogerka, bobnarka, boksarka, deskarka, dirkačica, domorodka, dramatičarka, fizičarka, frajerka, gimnastičarka, harmonikarka, imitatorka, improvizatorka, inovatorka, investitorka, kanclerka, komičarka, koncesionarka, konservatorka, konzervatorka, korepetitorka, kratkolaska, krmarka, krupjejka, kuratorka, labradorka, lončarka, mediatorka, milijarderka, moderatorka, očividka, performerka, piflarka, podsekretarka, promotorka, vampirka, vladarka, vremenarka, vrtnarka, zeliščarka, žurerka.

Pri moških prevladujejo oblike na -vec in -lec: kvizlingovec, objavljavec, 
pankovec; belilec, blebetalec, delilec, dostavljalec, dražilec, glodalec, hvalilec, kalilec, kramljalec, molilec, nabavljalec, nastavljalec, objavljalec, obnavljalec, obotavljalec, ponavljalec, popravljalec, pospravljalec, postavljalec, predstavljalec, prestavljalec, pripravljalec, spraševalec, spremljalec, streljalec, tajilec, talilec, tulilec, ugotavljalec, uhajalec, upodabljalec, upravljalec, valilec, volilec, zajedalec, zastavljalec, zmerjalec, žalilec.

Poleg tega še: alumen, avtodomar, blefer, debitant, divizijonar, folklornik, gimnastičar, ljudožrc, medievalist, medievist, podjemnik, podprvak, postrežček, sumoborec, triatlonec.

Pridevnikov je 79: analogen, andaluzijski, balzov, biometrijski, bizmutov, bleferski, bližnjičen, boemski, čartističen, členkoven, dampinški, debitantski, denotativen, desetevrski, desettisočtolarski, desettolarski, drugouvrščen, dvajsetevrski, dvajsettolarski, dvestoevrski, dvestotolarski, dvoevrski, fotovoltaičen, gluhoslep, grkokatoliški, gruzijski, hardverski, hiphopovski, histaminski, infrastrukturen, inštrukcijski, jakobov, jazzističen, jogurtov, kardiološki, klipinški, koktajlski, konzumacijski, konzumen, konzumentski, konzumpcijski, koruptiven, krajšaven, krasosloven, kvizlinški, lajmski, libidinalen, lymski, magijski, mangrovov, mazohističen, medgeneracijski, menedžerski, nadbesedilen, nizkocenoven, pankovski, petdesetevrski, petdesettolarski, petevrski, petstoevrski, petstotolarski, pettisočtolarski, pettolarski, podjemen, pomenskorazločevalen, ponazarjalen, ponski, predkazenski, spongiformen, spraševalen, stoevrski, stotolarski, tabloiden, terminatorski, tinejdžerski, tisočtolarski, wordov, žafranikin, želiren.

Izpeljani samostalniki, glagolniki, znanstvene vede, manjšalnice (36): arijanizem, čartizem, mazohizem, mesijanizem, zenbudizem, deinstitucionalizacija, felacija, hidracija, konzumacija, konzumpcija, donegovanje, dorisovanje, fafanje, iztisnjenje, konzumiranje, odvodnjavanje, ponastavljanje, poplačevanje, spraševanje, štopanje, želiranje, interdisciplinarnost, prekarnost, disleksija, inštruktaža, lezbištvo, posodobitev, 
šaljenje; etnolingvistika, fotovoltaika, medievalistika, medievistika, venerologija; dolarček, evrček, majčka.

Glagoli (22): certificirati, dorisati, dorisovati, fafati, falsificirati, hendikepirati, inovativnost, kolapsirati, konzumirati, nokavtirati, obelodanjati, odjavljati, odmaševati, odsvajati, pofafati, pohojati, poračunavati, prenakazovati, prerazdeljevati, prerazporejati, spraševati, všečkati.

Medmeti (6): aua, auč, auva, avč, čao, vau.

Specializirana področja in terminologija (18): biomarker, ferata, kapesanta, LED, ledica, lema, makron, makron, malus, mulda, orka, pilates, pojavnica, pona, prekariat, streljanka, validator, žafranika.

Iz SSKJ1 (dvojnice, zev), ${ }^{11}$ SNB (drugačna oblika) ali SP2001 (41): akrostihon, arboret, avtoštop, boema, boemstvo, buldozer, cojzit, čičerika, dendi, karavaning, kardamon, karitas, kerosin, konzumar, konzument, luksus, menedžerstvo, monsum, nonšalanca, papiros, tezaver; erlihioza, kip, nadbesedilo, zmenkarija; bifenil, endorfin, nanometer, surfinija, vitlof, zvin; amonijak, amonijakov, bastijon, divizijon, florijada, gimnaziada, gladijola, lijana, mirijada, olimpijada.

Spremembe zapisa, spola, števila in stilno zaznamovani (13): Alzheimerjev, brajica, brokoli, Jehovov, joška, parta, ara, činčila, panda, TV, vodja; fuk, pir.

Citatni in podomačeni zapis, okrajšave (40): ctrl, delete, derby, display, ju-jitsu, ju-jutsu, hardware, lobby, macaron, word; bejzbol, bekend, bluz, bombon, buli, damping, džudžic, džudžuc, džoint, foaje, forhend, frape, fuzbal, gril, interjer, kečap, lajtmotiv, menedžment, nokavt, nugat, spem, spidvej, srf, stejk, sving, šeri, šoa, šoah, tekila, timbilding.

Slovnične (2): milijon, nekogaršnji.

\footnotetext{
${ }_{11}^{11}$ To kategorijo opisujemo že v prvem poglavju, gre pa za tiste iztočnice, ki so bile na prehodu iz SSKJ1 v SSKJ2 statusno zamenjane iz iztočnice v dvojnico ali je bila dodana oblika, ki upošteva spremembe pri pisnem zapiranju zeva.
} 


\subsection{Težave z geslovnikom}

Bistvo težav z geslovnikom SSKJ2 ni na ravni vključitve te ali one iztočnice (kar bomo sicer vendarle izpostavili kasneje), temveč na ravni ideje oz. napačnega razumevanja koncepta prve izdaje SSKJ in popačenja temeljnega sporočila slovarskega izdelka, kakršen je bil dan v slovenski prostor pred petdesetimi leti. Za začetek lahko ponovno damo glas avtorjem prve izdaje SSKJ:

SSKJ (prva izdaja) je bil s svojo zasnovo in izvedbo vezan na gradivo, ki se je za ta slovar načrtno ekscerpiralo po različnih metodah, in sicer z zvrstno za tedanji čas (6o. leta prejšnjega stoletja) ustrezno uravnoteženega nabora različnih besedilnih vrst. Leksikalne enote so se sprejemale v SSKJ v skladu s kompleksnimi merili, ki nikakor niso bila omejena na pogostnost. Pri dopolnitvah za drugo izdajo pa je, nasprotno, kot edino merilo za sprejem imenovana zgolj »pogostost pojavitev v gradivu «, ki v zvezi s korpusnim gradivom še zlasti ni združljiva s konceptom SSKJ. Nove leksikalne enote so besedilu prve izdaje mehanično dodane ne glede na koncept SSKJ, brez upoštevanja specifičnosti korpusnega gradiva, zlasti pa brez razvidnih meril o sprejemanju (Ahlin idr. 2014: 122).

Slovenski jezik ima ustaljene in normativno preizkušene smernice glede sprejemanja prevzetih leksikalnih enot v pisavi in izgovoru, ki jeziku na izrazni ravni zagotavljajo ustrezno kultiviranost. Druga izdaja SSKJ teh smernic ne upošteva in se brez distance podreja številčnemu diktatu korpusov, namesto da bi v skladu s konceptom SSKJ upoštevala tradicijo kultiviranja slovenskega jezika, kot jo poleg načel Slovenskega pravopisa neposredno potrjujejo tudi slovenska besedila zborne zvrsti (ibid: 124).

To dilemo morda še najbolje ilustrira vprašanje, s katerim se soočajo lektorji, učitelji, uredniki, pravniki, pisci besedil, pri katerih se pričakuje določena mera »standardiziranosti« izdelka: »ali je ta beseda v SSKJ? « - če je ni, je splošna predpostavka, da bi z njo lahko bilo nekaj narobe. Ali v bolj samovšečni varianti: »izmislil sem si besedo, kako jo spravim v SSKJ?«12 Koncept SSKJ je

12 Ta tip leksikografskega dela se je lepo izrazil tudi pri natečaju Bodi UP!, v okviru katerega so bili izbrani trije zmagovalni glagoli za prostovoljstvo, ki jih je Slovenska filantropija iskala 
predpostavljal, da je že samo s tem, ko se je neko poimenovanje, beseda, leksem znašel v geslovniku Slovarja slovenskega knjižnega jezika, pridobil status »dela knjižnega jezika «, torej domovinsko pravico v knjižni slovenščini, ne glede na stilno ali drugo označenost. Kot navajamo v uvodu, so se avtorji SNB od tega koncepta oddaljili - Slovar novejšega besedja slovenskega jezika pravzaprav ni nič drugega kot to, kar pravi naslov: zbirka besedja, ki je bila zabeležena glede na pogostost pojavljanja v korpusih (predvsem v korpusu Nova beseda):

Pri sestavi geslovnika smo se oprli na zbirko novejšega besedja, ki je nastala v okviru projekta Novejša slovenska leksika ( $v$ povezavi s spletnimi jezikovnimi viri). Projekt, ki je potekal v Leksikološki sekciji Inštituta za slovenski jezik v letih 2007-2009, je bil zasnovan kot predstavitev nove leksike in leksikalnega stanja v slovenščini za dopolnitev zbirk in geslovnikov novejšega besedja za različne tipe slovarjev standardne slovenščine (SNB 2013: 9).

Koncepta knjižnosti, izbora besedišča z namenom kultiviranja jezika, v tem slovarju ni več, gre za beleženje besedišča, ki je povezano s procesom standardizacije. In vendar je bila večina geselskih člankov iz SNB vključena v SSKJ2, ne da bi bilo v slovarju mogoče jasno ločiti, kaj izhaja iz prve izdaje in kaj je bilo dodano.

To vprašanje bi lahko poimenovali tudi »fuzbalska dilema«. V Besedišču slovenskega jezika z oblikoslovnimi podatki (po gradivu za slovar sodobnega knjižnega jezika zbrane besede, ki niso bile sprejete v SSKJ; Besedišče 1998) se nahaja tudi iztočnica fuzbal. ${ }^{13}$ Čeprav je bila torej zabeležena že $\mathrm{v}$ času sestavljanja prvotnega SSKJ, vanj ni bila uvrščena in s tem ji ni bil dodeljen status knjižnosti - avtorji SSKJ1 so se izogibali vključevanju tega, kar je bilo

skupaj z mladimi in širšo javnostjo. V svojem govoru ob razglasitvi zmagovalnih glagolov je predstojnik Inštituta za slovenski jezik Frana Ramovša ZRC SAZU o izbrani besedi prostovoljiti izjavil. »Uporabljajmo jo in jo imejmo radi. Ker je tudi naš inštitut eden njenih botrov, jo $\mathrm{v}$ življenje pospremljamo $\mathrm{z}$ uvrstitvijo $\mathrm{v}$ Slovar novejšega besedja slovenskega jezika, kar že skoraj zagotavlja njeno pojavitev v drugi izdaji Slovarja slovenskega knjižnega jezika. /.../«. Spletna stran: http://www.prostovoljstvo.org/index.php?t=news\&id=905\&l=sl (dostop 25. 12. 2014). Glagol je bil na koncu uvrščen tako v SNB kot SSKJ2.

13 Dostopno na spletni strani: http://bos.zrc-sazu.si/besedisc.html. 
dojeto kot »neknjižno « in v SSKJ1, kolikor je ta del besedišča vključen, je moral izhajati iz »dobre literature«, označen pa je bil s kvalifikatorjem »nižje pogovorno«: afna, afnati se, arcnija, britof, cagati, cagav, cagavec, cagavost, cajg, cajgast, cenkati se, čorav, dila, dohtar, dohtarica, drat, draten, dratenka, džumbus, fana, farbati, fasati, fehtariti, fehtati, fejst, fentati, figa, figole, firbčen, firbec itd.

V novem SSKJ se iztočnica fuzbal nahaja z oznako "pogovorno«. Ključno je torej: če bi besedišče slovenskega jezika obravnavali na način, ki je bil uporabljen pri dodajanju elementov SNB v drugo izdajo SSKJ2, bi bila že prva izdaja SSKJ videti precej drugačna. Fuzbal kot zastopnik množice podobnih izrazov bi bil torej lahko že v SSKJ1 vključen z oznako "pogovorno«, če konceptualno izhodišče ne bi bila »knjižnost«. V tem smislu je v SSKJ2 »uslovarjena « in nekompatibilno predstavljena marsikatera iztočnica, ki po konceptu SSKJ1 ne bi prišla v slovar, med 178.457 iztočnicami BSJ pa je najbrž pozabljena marsikatera, ki ji nikoli ne bo dano prebiti se v slovar po enakem kriteriju. Rezultat je neuravnotežen geslovnik SSKJ2, pri katerem ni več mogoče razlikovati med geslovniškima konceptoma SSKJ1 in SNB, pri čemer v resnici nihče ne ve, po kakšnih merilih in po kakšni metodi je izbor iz SNB sploh prišel v SSKJ2. Ali ponovno z besedami avtorjev prve izdaje:

/.../ nova izdaja samovoljno vključuje dodatke, ki niso združljivi s konceptom SSKJ in z glavnino slovarskega besedila, prevzeto iz prve izdaje. Po tej poti se potvarja značaj SSKJ in površinsko vzbuja vtis posodobljenega pojmovanja zvrstno-stilne razčlenjenosti slovenskega jezika, dejansko pa se prikriva nedomišljenost te zahtevne in jezikovnokulturno občutljive problematike.

Tipični primeri te prakse so slengovski izrazi, npr. blúziti, búkla, comeback, čápec, čúk, džánki, džankizácija, fáca, falíti, féler, fíksar, fíksati, fôpati, fóra, frend, frendica, fŕka, fúl, gándža, gnjavátor, hórs, keš, kúl, lájf, lápati, levák, modél, nárkič, naspidíran, naspidírati, našpônati, nateg, nategníti, nategováti, pôfel, popéniti, sfalíti, símpel, šít, šít, špíl, špônati, štála, uživáncija, zezati, zíc, zíher, ziheráš, ziheráštvo. Ne gre za to, da ti izrazi niso zanimivi, da so 
nelegitimni, nevredni opisa in podobno, le v slovar, ki ima naslov »druga izdaja SSKJ «, v katerem je celo besedilo iz prve izdaje, ne bi smeli biti vključeni na način, kot so.

\subsubsection{SODOBNOST GESLOVNIKA - KAJ JE NEVTRALNO}

Ena od logičnih zadreg pri združevanju petdeset let starega geslovnika in novega dopolnila je kompatibilnost časovnih in drugih oznak, saj bi bilo aktualnost besedišča treba načeloma pregledati za celoten nabor iztočnic. Ta proces pri izdelavi SSKJ2 ni bil opravljen. V nadaljevanju je predstavljen manjši test, pri katerem je bilo pregledano besedišče črke F po dveh kriterijih. Ne glede na problematičnost podatkov o pogostosti iz korpusov neobstoj neke oblike oz. leme v obsežnem korpusu sodobnega pisnega jezika lahko indicira, da iztočnica ni več pogosto v obtoku v sodobni slovenščini. Prvi filter pri testu je bil torej ničta pojavnost leme in oblike v korpusu Gigafida. Drugi filter so bili kvalifikatorji, ki kažejo, da iztočnica ni (bila) del splošnega (sodobnega) jezika, ki ga lahko pričakujemo v sinhronem korpusu: časovno-frekvenčni (starinsko, zastarelo, nekdaj), terminološki (tehnika, fizika, geografija itd.), nekateri stilno-zvrstni (narečno). Navedene pa so iztočnice s kvalifikatorji, ki naj bi opredeljevali še živo besedišče (knjižno, pogovorno, slabšalno itd.) in je izraze tega tipa navadno mogoče najti v korpusih. Rezultat je naslednji:

- brez kvalifikatorja: fabianizem, fabrikacijski, fasadiranje, fasona, faustičen, feaški, feldvebelski, fevdalstvo, fideist, filologiziranje, fizkulturniški, flafot, fluorografsko, fofotanje, fofotati, fontologija, fosfornat, fosforov, fragmentaričen, fragmentaričnost, frazač, frfoleti, frfotniti, ftiziološki, fundamenten;

- pogovorno, nižje pogovorno, ekspresivno in slabšalno: fabričan, ferialec, fokselj, fračkač, frečkati, fikslavdon, figarstvo, figav, fantalinstvo, frkolinski, frliti, frtavka, frazast;

- knjižno in knjižno slabšalno: fronderstvo, faktorialen, faliten, fanfaronada, fasonirati, fejaštvo, filistejstvo, finansje, fraternizirati, fuzionirati, furtimaški. 
Že na prvi pogled je razvidno, da govorimo o neki drugi slovenščini, ki je danes ne bi smeli predstavljati kot nevtralne, žive in sodobne. Črka F predstavlja približno 1,5 odstotka slovarskega fonda, torej si lahko zamislimo, koliko je takih iztočnic v celotnem slovarju. Vsakdo, ki bo na spletu preverjal vsebino slovarja z letnico 2014, od učiteljev, učencev, lektorjev, piscev, govorcev tujih jezikov, ki se učijo slovensko itd., bo torej dobil popolnoma napačen vtis o tem, kakšen je sodobni slovenski jezik.

\subsubsection{SODOBNOST GESLOVNIKA - ČESA V SSKJ2 NI}

V primerjavi z zgornjimi navedbami si je smiselno ogledati tudi drugo plat, torej besede, ki jih geslovnik SSKJ2 ne vsebuje. Za ponazoritev, kakšna sodobna slovenščina dejansko je, lahko spet uporabimo podatke iz korpusa in jih primerjamo z geslovnikom SSKJ2. Ker je $\mathrm{v}$ ta geslovnik vključena večina iztočnic iz SNB, bi torej morali imeti na voljo opis sodobnega besedišča, ne glede na zadrege s slengovskimi in drugimi omenjenimi izrazi. Spisek v nadaljevanju navajamo kot izhodišče za razmišljanje o vključitvi iztočnice $\mathrm{v}$ slovar, ne kot sugestijo, da bi vse iztočnice morale biti tudi vključene. Kljub temu pa seznam ponuja dober občutek za sodobni jezik. Navajamo torej iztočnice, ki se v korpusu Gigafida pojavljajo s frekvenco nad 1000 zadetkov in niso bile vključene v Slovar slovenskega knjižnega jezika z letnico 2014.

Izpeljani samostalniki, glagolniki: dvigovanje (7445), upokojevanje (3941), diskreditacija (2934), blaženje (2720), upravičenje (2585), izključenost (2010), dognojevanje (1715), beleženje (1601), dopustovanje (1394), otekanje (1265), ubranitev (1245), razpoznavnost (1303), deregulacija (1193), nadgrajevanje (1135), simpatičnost (1125), poslovodenje (1095), depresivnost (1070), destabilizacija (1054), posoja (1050), razpečevanje (1028), obeležitev (1019).

Občni samostalniki, terminologija: turbodizel (4922), superpokal (4224), multinovela (3575), kombilimuzina (2600), megauspešnica (2564), avtoelektrika (2457), samonakladalka (2385), pripad (2280), osemvaljnik (2277), mokrišče (2196), tretjeligaš (2134), motokrosist (1960), superzvezdnik 
(1690), opoldnevnik (1656), soorganizator (1758), fundamentalist (1577), bovling (1553), monokomedija (1545), predator (1517), dvovaljnik (1311), superliga (1277), vodooskrba (1266), paracetamol (1214), motokultivator (1096), plavutnica (1085), miniserija (1068), brisalnik (1054), avdiosistem (1030), kompostiranje (1026).

Manjšalnice: novička (4990), mišek (4639), kuponček (2435), programček (2323), vesoljček (1070).

Pridevniki: privatizacijski (6727), biatlonski (6078), limuzinski (5986), petstopenjski (4025), drugoligaški (3946), tožilski (3816), šprinterski (3772), veččrkoven (3669), šiitski (3174), visokotehnološki (2739), rezultatski (2732), medbančen (2540), multinacionalen (2276), trilitrski (1868), enoprostorski (1797), miškin (2274), protidopinški (2068), arhetipski (1608), košarkaški (1606), medsosedski (1543), državnotožilski (1533), hčerkin (1506), obvolanski (1513), četrtouvrščen (1349), ksenonski (1346), branilski (1341), brezstopenjski (1310), vizumski (1287), zunajparlamentaren (1179), medetničen (1122), tiskalniški (1101), elektrodistribucijski (1092), večfunkcijski (1055), agroživilski (1056), supervizijski (1038), endoskopski (1026), blesav (1008).

Izlastnoimenski pridevniki: novomeški (64230), zagrebški (23555), novogoriški (22072), newyorški (21222), južnoafriški (12951), afganistanski (10123), korejski (9485), južnokorejski (6297), severnokorejski (4836), tajvanski (4733), beloruski (4200), pacifiški (4065), venezuelski (3748), apeninski (2974), filipinski (2930), luksemburški (2888), nigerijski (2840), severnoirski (2659), monaški (2579), kenijski (2245), severnoprimorski (2120), elizejski (1751), bolivijski (1483), valižanski (1446), kremeljski (1402), urugvajski (1241), čezatlantski (1159), moldavski (1154), šanghajski (1137), ekvadorski (1049).

Pravopisno težavni, stilno zaznamovani: nenazadnje (18885), ničkoliko (1010); svinjina (3280), fondacija (2669), meridian (2577), kampanija (1308); rokenrol (3996), komunajzar (1753), naftaš (1411). 
Merske enote: mikrogram (2068), mililiter (1468), njutonmeter (1030).

Glagoli: sproducirati (1398), destabilizirati (1163).

Sporno pri tem je tudi dejstvo, da so se avtorji SSKJ2 že v času po izdaji SNB odločili za sistemsko vključitev niza tvorjenk, ki imajo v sodobnem slovenskem jeziku ničto ali skrajno nizko pojavnost (npr. blebetalec, hvalilec, kramljalec, nabavljalec, objavljalec, objavljavec, obotavljalec, spremljalec, streljalec, tajilec, tulilec, ugotavljalec, uhajalec, valilec, žalilec; molilka, ponavljalka, pospravljalka, pregledovalka, tožljivka, valilka, zmerjalka) ali je celo nimajo. Po drugi strani pa je bil v procesu mehaničnega lepljenja geslovnika SSKJ1 in SNB zgrešen cel niz iztočnic, ki bi verjetno zaslužile mesto v okviru »slovenskega knjižnega jezika «.

Del prispevka o geslovniku SSKJ2 lahko sklenemo z nekaj ugotovitvami. Avtorji so razen nekaj izjem ohranili skoraj vse iztočnice iz SSKJ1, vendar so v podobo geslovnika posegli s preurejanjem statusa iztočnic, podiztočnic in dvojnic, $s$ čimer so brez razvidnega mandata, bodisi SAZU ali koga drugega, posegli v pravopisno in pravorečno podobo slovenskega »knjižnega jezika «. Ti posegi v besedilu slovarja niso razvidni in jih navadni uporabnik nikakor ne more prepoznati brez vsakokratne primerjave s SSKJ1 in SP2001. Z nikjer pojasnjenim in nediskriminativnim vključevanjem novih geselskih člankov iz Slovarja novejšega besedja slovenskega jezika, ki je imel drugačno izhodišče izbora iztočnic kot SSKJ1, je v SSKJ2 razrušena konsistentna obravnava besedišča, s čimer je spodkopan tudi koncept »knjižnosti« iz prve izdaje. Ali z drugimi besedami: »Kar je zapisano $\mathrm{v}$ slovarju, nima več vrednosti referenčnega podatka, zato je skoraj vseeno, kaj se zapiše v slovar in koliko je to usklajeno s preostalim slovarskim besedilom « (Ahlin idr. 2014: 126). In nazadnje: že upoštevanje frekvenčnih podatkov iz korpusa bi lahko prispevalo $\mathrm{k}$ temu, da bi bilo dejansko obravnavano aktualno besedišče, ki je pogosto rabljeno in nevtralno. A tudi proces korpusne analize ni bil izpeljan uspešno, kot smo pokazali zgoraj, k čemu je najbrž levji delež prispevala zvrstna 
neuravnoteženost in jezikoslovna neoznačenost izhodiščnega korpusa, na kar je bilo v tem prostoru opozorjeno že ničkolikokrat (Logar 2009, 2014; Gantar 2014).

\section{VSEBINA GESELSKIH ČLANKOV}

Pri drugi analizi smo izbrali 2.500 geselskih člankov iz SSKJ1 in jih primerjali z ustrezajočimi članki iz SSKJ2. ${ }^{14}$ Torej so bili iz analize izključeni geselski članki iz SSKJ2, ki jih v SSKJ1 ni. Za analizo je bilo pri vsaki črki iz geslovnika izločenih sto zaporednih člankov, pri čemer je bila pri črki A kot izhodiščna iztočnica izbrana absolutizírati ter naslednjih 99 člankov. Pri vsaki naslednji črki je bila kot prva iztočnica iz te črke izbrana tista s prištetimi stotimi članki. Pri črki B se spisek stotih torej začenja z iztočnico bakroréznica kot dvestoto po vrsti od začetka črke B, pri C s centrízem kot tristoto od začetka $\mathrm{C}$ itd. Če po tej formuli ni bilo mogoče izbrati člankov, ker v črki ni bilo dovolj iztočnic (npr. črka Š), so bili izbrani članki zadnje polne stotice. Če je bilo npr. geselskih člankov v črki 1.762 in bi morali biti izbrani tisti med 1.900 in 2.000 , so bili izbrani geselski članki med 1.600 in 1.700 . Na ta način je bilo mogoče opazovati obravnavo zaporednih gesel, pri distribuciji po črkah pa je bila ohranjena relativna razpršenost vzorca.

Razlike obravnavamo po naslednjih temah: spremembe pri razlagah, pri oznakah oz. kvalificiranju, pri izgovoru, pri zgledih. Zadnji temi sta splošnejši: pravopis in slovnica.

\subsection{Razlage}

Najbolj opazna in pogosta sprememba pri razlagah je sistemska pretvorba pri feminativih iz posredne oz. sklicevalne razlage - »ženska oblika od ...« v klasično razlago, tipično »ženska, ki ...«, npr. absolvêntka ženska oblika od absolvent $\rightarrow$ ženska, ki dokonča šolo. Razlaga je v vseh omenjenih primerih

\footnotetext{
14 Dokument s primerjavo v obliki sledenja spremembam. Dostopno prek:
} http://www.trojina.org/slovenscina2.o/arhiv/2014/2/Spiski/SSKJ_1-2.zip. 
prepisana iz že obstoječe moške oblike in teh sprememb pri analizi ne upoštevamo. V analiziranih 2.500 geselskih člankih so pomeni dodani v 22 geselskih člankih, od tega $\mathrm{v}$ štirinajstih na podlagi zabeleženih novih pomenov iz SNB. Preostali dodani pomeni so $\mathrm{v}$ naslednjih osmih člankih: balinar (športnik), hobotnica (pridobivanje koristi), junkers (bombnik), mehek (ki ima blažji učinek), narodnjak (glasbenik), shizofrenija (stanje notranje napetosti), shizofrenik (kdor čuti notranjo napetost), voznik (tekmovalec). Na podlagi analize 2.500 geselskih člankov statistično torej lahko pričakujemo nove pomene, ki jih ni nikjer drugje kot v SSKJ2, v nekaj več kot treh promilih iztočnic iz prve izdaje SSKJ ali skupaj v okrog 300 geselskih člankih SSKJ2.

Že obstoječe razlage v SSKJ1 so spremenjene v 21 iztočnicah, dve zaradi politične korektnosti (defektologija, pigmejec), preostale so: balista, balkanizacija, balkon, defloracija, deflorirati, jura, kavsati, kazina, kazino, narkoman, narkoman, narkomanija, narkomanstvo, štuka, vozač, župan, županija, županja, županovati, županstvo. Spremembe v besedni družini župan itd., kazina in kazino izhajajo iz menjave družbenega sistema, pri čemer je bilo treba uskladiti sedanjo in preteklo politično funkcijo župana ter vojaške nazive (oficir = častnik). Balkanizacija je dobila obširnejšo razlago, ki upošteva zadnje vojne na Balkanu. Razlaga pri defloracija / deflorirati je bila spremenjena iz medicinske $\mathrm{v}$ splošno (himen = deviška kožica). Pri kavsati je sprememba manj razumljiva. SSKJ1 je imel razlago drugega pomena $\mathrm{s}$ kvalifikatorjem »vulgarno« spolno občevati, ki je spremenjena $\mathrm{v}$ imeti spolne odnose, opravljati spolno združitev (s kom). Zanimivo bi bilo izvedeti, od kod motivacija za to menjavo, ki je izvedena enotno po celotnem slovarju, torej tudi pri: fukati, jebati, kavsati, koitirati, ljubiti, občevati, pariti, porivati, posiljevati, prešuštvovati, seksati, spati. Besedna družina narkoman itd. je dobila politično korektnejšo oz. verjetno tudi medicinsko ustreznejšo razlago ( $k$ dor uživa mamila iz bolezenske sle $\rightarrow$ kdor je zasvojen z mamili). Pri iztočnici vozáč je razlaga voznik (avtomobila) izgubila avtomobil.

Indikativne spremembe lahko opazujemo pri geslih balista in balkon: 
balísta -e ž (î) $v$ starem in srednjem veku vojaška priprava za metanje kamenja (SSKJ1)

balísta -e ž (î) $v$ starem in srednjem veku navadno velikemu samostrelu podobna vojaška priprava za metanje izstrelkov, zlasti velikih puščic, kopij: napenjati, pomikati balisto; baliste in katapulti / maketa baliste (SSKJ2)

balkón -a m (ộ) ograjen pomol iz hišnega zidu, z vrati povezan z notranjimi prostori: /.../ (SSKJ1)

balkón -a m (ọ) ograjena ploščad, ki moli iz zidu stavbe, navadno stanovanjske, in je z vrati povezana z notranjimi prostori: /.../ (SSKJ2)

Ti dve gesli lepo kažeta na težave, na katere opozarjajo tudi avtorji prve izdaje: »Razlage so enciklopedične, zunaj razlagalnega sistema SSKJ (vključujočega ustaljene tipe uvrščevalnih in razločevalnih pomenskih sestavin, jedrnatost; /.../« (Ahlin idr. 2014: 125). Med spremenjenimi ali dopolnjenimi geselskimi članki se izrazito neuravnoteženo pojavljajo iztočnice $s$ področja vojaške tehnike (balista, štuka, junkers). Vprašanje je namreč, ali je ravno balista med desettisoči nespremenjenih geselskih člankov tisto geslo, ki rabi tako obsežen popravek enciklopedične narave. In vprašanje je, kaj vsi dodani zgledi rabe dodajo k razumevanju pomena. Zdi se, da so ti popravki arbitrarni, še več, pojavljajo se bolj ali manj samo $\mathrm{v}$ geslih, pri katerih so bili sistemsko spremenjeni kvalifikatorji. Ponuja se vtis, da so bile razen sistemsko določenih posegov redakcije opravljene s skakanjem po kvalifikatorjih, ad hoc, glede na preferenčna področja redaktorja ali redaktorice.

Pri balkonu je popravek še zanimivejši. Iz primerjave obeh verzij razlage je na prvi pogled jasno, kaj je bilo mišljeno s prej omenjeno »jedrnatostjo «. V SSKJ1 je razlaga pri balkonu skrajno ekonomična. Poleg tega, da je v SSKJ2 podaljšana z oziralnim odvisnikom in še s pristavkom, je spremenjena tudi nadpomenka, genus proximum, ki je eden od občutljivejših delov razlage. V SSKJ2 je nadpomenka iz »pomola« spremenjena v »ploščad«. Poglejmo si, katere iztočnice so v SSKJ1 opredeljene z genusom »pomol «: balkon, izzidek, konzola, 
prižnica, tin. In »ploščad «: esplanada, gredina, platforma, plato, pločad, ploščada, ploščadka, rampa. Očitno je, da je bil pomol sistematično uporabljen za opis stanja, ko nekaj štrli ali moli iz vertikalne površine, ploščad pa vedno, ko gre za horizontalni objekt na tleh. Najbrž nevede je redaktor podrl minuciozni, skozi redaktorsko delo zgrajeni sistem razlag v prvi izdaji SSKJ. Taki in podobni posegi kažejo, da je bila redakcija opravljena brez dejanske navezave na znanja, ki na inštitutu nedvomno včasih so obstajala, ob prvem seznanjanju redaktorjev z leksikografskim delom. Očitno se je inštitutskemu vodstvu to zdelo primerno za delo, kot je druga izdaja SSKJ.

Razlagam v prvi izdaji SSKJ je nedvomno mogoče marsikaj očitati, kritike so pogosto izpostavljale nerazumljivost in zapletenost (Rozman 2010; Müller 2009), zato je o razlagalnih praksah vsekakor treba razmisliti na novo. Nedvomno pa bi se bilo treba tega lotiti sistematično in celostno, ne pa z naključnimi popravki, brez zavedanja, na kakšni podlagi so prvotne razlage sploh nastale.

Omenjenim spremembam se na koncu pridružuje še pet terminoloških popravkov s področja prava (trajen, užitek), fizike (elementaren), ekonomije (naroden) in jezikoslovja (intonacija). Zanimiva bi bilo dobiti pojasnilo za spremembo pri elementaren, kjer je pri zvezi »elementarni naboj« v razlagi (pozitivni ali negativni) naboj spremenjen v (negativni ali pozitivni) naboj.

\subsection{Oznake}

V sistem kvalificiranja so redaktorji SSKJ2 dokaj močno posegli in to je pravzaprav ena od večjih težav končnega izdelka. $V$ tem razdelku obravnavamo vse kvalifikatorje razen slovničnih, ki so obdelani v razdelku o slovnici. Začenjamo s tehničnimi spremembami - nekaj oznak je bilo zgolj preimenovanih (lingv. $\rightarrow$ jezikosl., muz. $\rightarrow$ glasb., jur. $\rightarrow$ pravn., astr. $\rightarrow$ astron.). Od tod dalje so vsi posegi v kvalificiranje iz SSKJ1 precej zanimivi.

V celoti je bilo izbrisano pojasnilo redko, ki kaže vso stisko minimaliziranega 
prenavljanja petdeset let starega slovarja. Namreč: redko glede na kaj? Ker je SSKJ1 nastajal na definiranem gradivu, je bilo nek pomen, zvezo itd. mogoče opredeliti glede na pojavnost tega $\mathrm{v}$ gradivu, te referenčne točke pa seveda ni več. Če je zaradi časovne distance večina slovarske vsebine »redka«, bi bilo precej neugodno ohranjati pojasnilo, ki kot redko opredeljuje slovarsko vsebino s stališča 70. in 80. let prejšnjega stoletja. Ker polovici slovarja ni mogoče dodajati pojasnila redko, ga je seveda treba izbrisati. Večinoma so ta pojasnila dejansko izginila iz geselskih člankov, kar pomeni, da so te iztočnice, pomeni, zveze ali zgledi nenadoma postali nevtralni, neločljivi od vsega, kar se je avtorjem SSKJ1 zdelo na robu smiselnosti vključitve. V nekaterih primerih pa je bilo pojasnilo zamenjano s kvalifikatorji »zastarelo«, »starinsko«, »ekspresivno« in »pogovorno«.

Če kvalifikatorskega sistema SSKJ1 ne poznamo in z išči in zamenjaj skačemo po pojasnilu redko, lahko hitro pridemo do tega, da neko besedo ali pomen, ki je bil prej označen kot knjiž. redko kvalificiramo s kombinacijo knjiž. zastar. (baladar, basniti, lužiti se, mazen, mejašiti, mesilnica, naplava itd.), kar je s stališča SSKJ1 nesmisel, saj je lahko ta (beseda/pomen) bodisi knjižna bodisi zastarela ali starinska, ne more pa biti oboje hkrati. S stališča sistema SSKJ je enako nenavadna tudi menjava redko $\rightarrow$ ekspresivno:

trajati redkø ekspr. ti čevlji trajajo se ohranjajo; so trpežni; redkø ekspr. ta pričeska dolgo traja je obstojna

ali redko $\rightarrow$ pogovorno:

vozáč 2. redkø pog. voznik (avtomobila): bil je preudaren vozač.

Težko je razumeti, kaj je ekspresivnega pri ti čevlji trajajo ali pogovornega pri bil je preudaren vozač, pri čemer tega pomena seveda ne moremo zaslediti v sodobni slovenščini, zdaj pa je nenadoma del pogovornega jezika. Podobno kot redko je spremenjeno tudi pojasnilo raba peša.

Med SSKJ1 in SSKJ2 je precej prehajanja med oznako žarg. (žargonsko) in pog. 
(pogovorno). Prva je v obeh tudi definirana drugače:

[SSKJ1] žarg. - Beseda, pomen ali zveza iz govora posameznih stanov. Če je raba omejena na ozko področje, je dodan ustrezni terminološki kvalifikator (cvek, defenzivka).

[SSKJ2] žarg. - Kvalifikator žarg. vedno nastopa v kombinaciji z ustreznim terminološkim kvalifikatorjem (npr. glasb. žarg.) in tako označuje strokovno pogovorno leksiko, ki ni znana širšemu krogu, temveč predvsem poznavalcem področja (broker, brucmajor, semplati).

Ker je bilo sprejeto načelo, da mora biti ob žarg. vedno terminološki kvalifikator, je bilo treba vse tiste, ki ga v SSKJ1 niso imeli, spremeniti v nekaj drugega ali izbrisati. Od tod tudi menjava žarg. $\rightarrow$ pog. pri iztočnicah: baletka (čeveljčki), mehovka (kamera), štuka (letalo), voz (avtomobil) itd. Koliko se v sodobnem pogovornem jeziku uporablja štuka za tip letala, voz za avtomobil, mehovka za kamero itd., bodo morali pojasniti redaktorji SSKJ2. Ali denimo pri geslu odlika, pri katerem je bil pri drugem pomenu izbrisan kvalifikator žarg., šol. in zamenjan s pog., pomeni pa »odlični uspeh « s pogovornim (!) zgledom prizadevati si za odliko.

Splošni vtis pri prilagajanju kvalifikatorskega sistema je ta, da je šlo veliko prizadevanja v spremembe izbrane peščice kvalifikatorjev po celotnem slovarju, vendar je rezultat brez podrobnega razumevanja sistema v SSKJ1 nenavadna mešanica »stare« in »nove« slovenščine, pri kateri je zdaj težko razumeti, kaj je sodobno in kaj dejansko spada ali je spadalo v določene zvrsti jezika nekoč in danes.

\subsection{Zgledi}

Pri zgledih je vseh sprememb v vzorcu 126. Največja prepoznavna skupina so tisti, ki so bili izbrisani ali spremenjeni zaradi elementov prejšnjega družbenega sistema, NOB-jevstva ali jugoslovanskosti:

čestítati -am /.../ ob dnevu republike čestitamo vsem delovnim ljudem 
deformácija -e /.../ deformacija socialistiěnih odnosov

interpretácija -e /.../Prešernove pesmi v Kidriěevi moderni interpretaciji ${ }^{15}$

literarizíran -a -o: literarizirani spemini na narodnoesvobodilni bej roman je literarizirana biografija

národ -a /.../ evropski, jugøsłovanski azijski narodi

razràst -ásta /.../ velik razrast narodnoesvobedilnega gibanja korupcije

uzakonítev -tve /.../ uzakonitev delavskega samoupravljanja večinskega volilnega sistema

vósovec -vca /... / rosere je likvidiral izdajalea očeta so jim ustrelili vosovci;

V nekaterih primerih tovrstna neprimernost niti ni razvidna na prvi pogled:

absorbírati -am /.../ tržišče ne more absorbirati łse industrijske proizvodnje znanje tujih jezikov;

cepítev -tve /.../ cepitev sveta na bloke delnic; cepitev družbe v razrede občine, stranke

uzakóniti -im /.../ uzakoniti nova načela v kolektivu podjetju

Sicer pa je pri spremembah v zgledih precej zanimivosti, ki ne vplivajo ključno na vsebino slovarja, vendarle pa se iz njih kažejo neke splošne tendence, ki so opazne pri ekipi, ki je slovar prenovila. Ena med njimi je ta, da so zgledi dodani tudi tam, kjer pravzaprav ne prispevajo k razjasnitvi pomena.

bakteriologíja -e ž (î) veda o bakterijah: sodobna bakteriologija

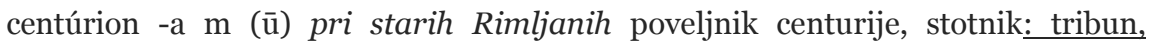
centurioni in legionarji

Drug opazen trend je dodajanje precejšnjega števila zgledov pri iztočnicah, ki niso zelo zahtevne. To najbrž kaže na implicitno željo po dodajanju podatkov o kolokativnosti v tipičnih skladenjskih strukturah:

15 Zanimivo je, da je v tem zgledu oče France Kidrič, literarni zgodovinar, po vsej verjetnosti doživel izbris zaradi sina Borisa Kidriča, komunista, partizana in narodnega heroja. 
interprétinja -e ž (ệ) interpretka: igriva interpretinja komičnih vlog; izvrstna interpretinja ženskih likov / iskrena interpretinja novih skladb; odlična interpretinja francoske glasbe

interníst -a m (î) zdravnik specialist za interno medicino: zdravil ga je znan internist; napotiti bolnika k internistu; posvet kardiologov, kirurgov in internistov /specialist internist

jumbo jet /.../ orjaški, velikanski jumbo jet; pilot jumbo jeta; nova, podaljšana, zgodnja različica jumbo jeta; strmoglavljenje, ugrabitev jumbo jeta / tovorni jumbo jet / letalo jumbo jet

$\mathrm{V}$ petnajstih primerih so dodane tudi stalne besedne zveze, npr. fiskalno pravilo, športni fiziolog, ulično gledališče, parkirni listek, notranji odkup, jedrsko odlagališče itd.

Nasploh pregled sprememb lahko potrdi tezo, da so slovarski zgledi močno sredstvo subtilnega usmerjanja uporabnika slovarja v neeksplicirane odtenke interpretacije pomenov (Gorjanc 2014). V uvodu v SSKJ2 je navedeno:

Posodobitve kvalifikatorjev, kvalifikatorskih pojasnil, pomenskih razlag in ponazarjalnega gradiva so izpeljane $\mathrm{z}$ namenom, da natančneje prikažejo stanje $\mathrm{v}$ sodobnem knjižnem jeziku, vendar ob tem ne izključujejo jezikovne resničnosti dobe, ki jo opisuje prva izdaja.

$\mathrm{V}$ resnici zadnjega dela izjave po analizi zgledov ne moremo potrditi. V ponazarjalnem gradivu je bil izbrisan precejšen del resničnosti dobe pred letom 1991. Zdi se, da bi bilo pravzaprav najbolje za celoten slovar narediti primerjavo zgledov, kakršna je bila izvedena na vzorcu 2.500 geselskih člankov. Že na sebi bi bilo s sociolingvističnega stališča dragoceno videti, katero resničnost iz časa SSKJ1 se je ekipi avtorjev SSKJ2 zdelo nujno prevrednotiti za nazaj.

\subsection{Izgovor}

Spremembe na ravni izgovora smo večinoma obravnavali že $\mathrm{v}$ poglavju o geslovniku. Če odštejemo sistemske spremembe, je v analiziranem vzorcu teh intervencij 56. Med sistemske spremembe štejemo prenos informacije o 
naglasu z iztočnice v zaglavje, ki je posledica odločitve, da se vse posebnosti v izgovoru, ki so v SSKJ1 zapisane v okrajšani obliki, v SSKJ2 zapisane za celo besedo, vključno z naglasom. Med analiziranimi spremembami v 54 primerih gre za standardni, že v SP2001 uveljavljeni »e pred $\mathrm{j}$ in o pred $\mathrm{v} \ll . \mathrm{V}$ dveh primerih je dodan variantni izgovor (kazíno -a in kazinó, lístkoven in listkôven). $\mathrm{V}$ večjem številu primerov je prišlo tudi do menjave »in« v »tudi«, ki iz enakovrednih možnosti pri izgovoru prvo spreminja v preferenčno, npr. lítina intudi litína.

\subsection{Pravopis}

Pravopisne oz. lektorske intervencije predstavljajo zanimivejši del analize vzorca. Pri teh se tudi najbolje vidi, da je precejšen del prenove potekal po načelu išči in zamenjaj. Najbolj tipična lektorska popravka te vrste $v$ opazovanih 2.500 geselskih člankih sta para področje/območje in sekta/ločina. Od 15 splošnih popravkov, ki smo jim pripisali oznako »pravopis«, jih kar 11 pripada tema menjavama. Torej ob vseh drugih možnostih lektorskih popravkov, ki so bili ob prenovi na voljo, precej izstopata. Malce tragikomično je, da so bile iz starega SSKJ izgnane vse sekte in spremenjene v ločine (adamit, albižan, bičar, donatist, flagelant, farizej, katarec itd.), medtem ko so sekte iz SNB imele pravico ostati nelektorirane tudi v SSKJ2. Tako imamo torej v razlagah ali ponazarjalnem gradivu sekte le še pri iztočnicah amiš, raeljanec, raeljanski, scientološki in vahabit, ki izhajajo iz SNB. Edina sekta, ki se je uspela kot taka prebiti iz SSKJ1 v SSKJ2, so - satanisti. Preostali lektorski popravki so: radiom/radiem (cenzura), hrvatskem/hrvaškem (fiškal), hobby/hobi (hobi), bolniei/bolnišnici (odležati).

Pri prenovi je bilo precej pozornosti namenjene tudi pisavi skupaj in narazen. Po celotnem besedilu so bile tako polektorirani prislovni in drugi pari tipa өdkøder/od koder, edkød/od kod, narahle/na rahlo, naredkø/na redko, ěimprej/čim prej, podolgem/po dolgem, natihem/na tihem, semintja/sem in tja itd. Takih primerov je $\mathrm{v}$ pregledanih geselskih člankih 11. Leksikografsko 
precej nenavadna se zdi rešitev, ki so jo pri prenovi ubrali avtorji SSKJ2 v stiski usklajevanja sprememb glede pisave skupaj in narazen s SP2001. Trije primeri iz vzorca:

narédko in na rédko prisl., piše se narazen (ē) 1. izraža razvrščenost /.../

odkód in od kód prisl., piše se narazen (ọ) 1. izraža vprašanje /.../

odkóder in od kóder [otkodər] prisl., piše se narazen (ộ) v vezniški rabi /.../

Torej, iz SSKJ1 se v SSKJ2 prenaša sugestija, da sta zapisa skupaj in narazen v iztočnici in dvojnici variantna, enakovredna, takoj zatem pa uporabnik v SSKJ2 dobi še temu nasprotujoč normativni signal, da je edina pravilna oblika pisana narazen.

Naslednja kategorija s pravopisnega področja je velika in mala začetnica. Popravkov te vrste je v vzorcu pet, v štirih od petih primerov gre za »cerkveno « tematiko. Če je stari SSKJ pod vplivom socialistične ideologije religijo skušal detronizirati tudi z uporabo male začetnice za vse vrste cerkva, je po drugi strani SP2001 to popravljal z uporabo velike začetnice za cerkvene ustanove. A vendar se tudi v SP2001 v razlagah še nahaja mala začetnica tudi pri cerkvenih ustanovah (patriárh -a [ija] m, člov. (a) srbske pravoslavne cerkve). SSKJ2 tu gre korak dlje, saj je velika začetnica uporabljena tudi v razlagah tipa:

cerkveni zbor zborovanje škofov in teologov, na katerem rešujejo vprašanja doktrinarnih in disciplinskih zadev eerkue Cerkve julijánski /... / julijanski koledar se uporablja v pravostauni Pravoslavni cerkvi Zadnji od petih popravkov na temo velika/mala začetnica odpira razmeroma obsežno in težavno pravopisno področje »svojilnih pridevnikov iz besed, pisanih z veliko začetnico« (Dobrovoljc 2004: 156-162). Gre za iztočnico Elijev.

[SSKJ1] Elíjev -a -o prid. (i) elektr., v zvezi Elijev ogenj in elijev ogenj svetlikanje na strelovodu zaradi razelektrenja ob nevihti [SP2001] elíjev in Elíjev -a -o (i) elektr. ogenj |svetlikanje na strelovodu| 
[SSKJ2] Elíjev -a -o prid. (î) elektr., v zvezi Elijev ogenj svetlikanje na strelovodu zaradi razelektrenja ob nevihti:

Po izidu prve knjige SSKJ se je razvila obsežna debata na temo, ali takšne zveze pisati v veliko ali malo začetnico. Toporišič je kritiziral rešitve v SSKJ, kjer je bila preferirana velika začetnica (Adamovo jabolko, Ottov motor, Rubikova kocka itd.), in v SP2001 kot preferenčno uveljavil malo začetnico (elijev ogenj, adamovo jabolko, ottov motor itd.). V SSKJ2 se torej vrača preferenčna oblika z veliko začetnico, pri čemer je pri Elijevem ognju ostala tudi edina možna oblika, za razliko od denimo adamovega jabolka in ottovega motorja, kjer sta še vedno navedeni obe. $\mathrm{V}$ okviru izdelave SSKJ2 je torej delovala pravopisna komisija brez mandata, in to celo ob hkratnem obstoju uradno imenovane Pravopisne komisije, ki pa nikjer med avtorji, v uvodu ali kjerkoli drugje ni omenjena.

Zadnja obravnavana tema je znamenita končnica lec-vec, ki je v šestdestih letih prejšnjega stoletja sprožila pravo pravopisno vojno. Večina teh sprememb se je v obliki dodanih iztočnic sicer zgodila na ravni geslovnika, saj je v novem slovarju veliko število dvojničnih oblik, kar že opisujemo $\mathrm{v}$ predhodnem poglavju. $\mathrm{V}$ pregledanem vzorcu imamo kot dvojnico dodano obliko na lec pri zastavljalec $^{1}$ in zastavljalec ${ }^{2}$.

Znotraj tega poglavja lahko opozorimo še na sistemsko opustitev oznake neustalj. To dejanje nevtralizira tvorbe, ki jih je SSKJ1 z normativnega vidika želel označiti bolj normativno kot z oznako publicistično, ki se je v SSKJ2 ohranila. Kot primer: čestitati na ozdravljenju, ki jo oba normativna priročnika, SP1962 in SP2001, na katera se sestavljavci SSKJ2 sklicujejo pri drugih vprašanjih (npr. pri zapisu malih in velikih začetnic), je postala v SSKJ2 nevtralna zveza s pojasnilom. Predpostavljamo, da sprejemanje tovrstnih odločitev ni bilo sprejeto v soglasju z normativnimi oz. standardizacijskimi telesi. 


\subsection{Slovnica}

V vzorcu se nahajajo samo štiri spremembe, ki smo jim pripisali tematiko »slovnica «, in sicer pri iztočnicah trak, kjer gre za legitimen popravek, saj geslo do sedaj sploh ni imelo osnovne besednovrstne opredelitve; češ, pri katerem gre za menjavo besedne vrste iz prislova v členek; čenda, pri katerem je zamenjan medmet s členkom; pika, kjer je 6. pomen dobil opredelitev »v členkovni rabi« namesto »v predmetni rabi «. Te spremembe zgolj nakazujejo večje menjave pri besednih vrstah, ki so v uvodu (SSKJ2 2014: 7) opisane takole:

Glede na Slovenski pravopis 2001 sta bili iz prislova osamosvojeni besedni vrsti členek in povedkovnik. Že v prvi izdaji uveljavljenemu kvalifikatorskemu pojasnilu $\mathrm{v}$ povedni rabi se je zato pridružilo novo $\mathrm{v}$ členkovni rabi.

Sama tematika t. i. osamosvojenih besednih vrst je bistveno prekompleksna za ta prispevek, zato bomo v nadaljevanju le nakazali problematiko, kakor se kaže v drugi izdaji SSKJ, v celoti pa vsebuje nekaj točk, ki čakajo na kritično obravnavo.

Najprej povedkovnik. V prvi izdaji SSKJ te besedne vrste še ni bilo, saj jo je uveljavil Toporišič v slovnici, katere prva izdaja je izšla po začetku izhajanja SSKJ (Toporišič 1976). Sistem besednih vrst v SSKJ je v osnovi izhajal iz slovnice štirih (Bajec idr. 1956). Novo besednovrstno razvrstitev je poleg slovnice vseboval tudi novi pravopis iz leta 2001. V njem je $\mathrm{z}$ oznako povedkovnik opredeljenih 486 iztočnic. Med njimi je veliko takih, ki imajo v SSKJ1 pojasnilo »v povedni rabi« (496) ali »v povedno-prislovni rabi« (54): čudno (je), dolgočasno (je), dvomljivo (je), čudež (je), greh (je) itd. Pred avtorji SSKJ2 je bila torej dilema: ali ostati pri besednovrstnem sistemu iz leta 1956 ali prilagoditi cel SSKJ novim besednim vrstam? Glede povedkovnika je rešitev nenavadna, na prvi pogled tudi ne preveč smiselna. Znano je, da se je strokovna javnost uvedbi povedkovnika močno upirala, zato tudi ni vključen kot besedna vrsta v šolske učbenike za slovenski jezik. Kljub temu je povedkovnik naveden med besednimi vrstami v uvodu v SSKJ2, torej so se avtorji odločili vsaj za 
kompromis. Namesto več sto povedkovniških iztočnic iz SP2001 pa jih je v SSKJ2 zgolj 10 (bòt, kós, kvít, predôlgčas, preškóda, pretemà, prerés, premràz, tréba, všéc). V ostalih primerih je uporabljena rešitev iz SSKJ1 »V povedni rabi«, iztočnice pa so ostale prislovi, samostalniki, pridevniki itd. Izbor desetih povedkovnikov se zdi skrajno nenavaden. Če so dolgčas, škoda, tema, mraz lahko samostalniki v povedni rabi in res členek v povedni rabi, zaradi petih elativov uvajamo novo besedno vrsto? Zakaj so iz množice povedkovniških kandidatov izbrani prav bot, kos, kvit, treba in všeč? Kaj se je zgodilo s fer, hec, kontra, križ, moč, okej, prav, rad, štos in množico drugih? Nova besedna vrsta z desetimi nenavadnimi iztočnicami? Skratka, kaže, da je kompromis namenjen temu, da je v uvodu mogoče navesti povedkovnik kot besedno vrsto, ki je vključena, potihoma pa je v celoti ignorirana, z nekaj bolj ali manj naključnimi iztočniškimi žrtvami, ki so opredeljene s to kategorijo.

Podobno zgodbo lahko gledamo pri členku. V SSKJ1 je bilo $\mathrm{s}$ to besedno vrsto označenih osem iztočnic (bi, bodi, ga, koli, le, le, naj, si). Ta obravnava je konsistentna z izhodiščem predtoporišičevske slovnice:

Med oblikovne prvine prislovnega značaja moramo šteti različne besedice ali tudi le osamljene glasove, ki se uporabljajo samostojno ali pa kot navezek drugim besedam in ki nimajo samostojnega pomena, a včasih premaknejo pomen, včasih pa besede okrepijo. Pravimo jim členki ali partikule (Bajec idr. 1956: 280).

V SP2001 je členkov 206, obravnavani pa so s povsem drugačnim izhodiščem:

Členki (ali partikule) so nepregibna besedna vrsta: z njimi vzpostavljamo zveze s sobesedilom, izražamo pomenske odtenke posameznih besed, delov stavka, celih stavkov in povedi ali pa tvorimo skladenjske naklone. Nekateri členki se po vlogi približujejo veznikom, drugi prislovom (Toporišič 2000: 445).

Koliko je torej členkov v SSKJ2? 193, a pogosto povsem drugih kot v SP2001. Poglejmo nekaj primerov.

- Iztočnica akurat je v SSKJ1 opredeljena kot prislov, v SSKJ2 kot členek. Kvalificirana je z zastarelo in razložena s »prav, natanko: akurat tako je 
hotel imeti . Iztočnici prav in natanko sta v istem slovarju opredeljeni kot prislova, ki imata ustrezne pomene opredeljene s pojasnili »v členkovni rabi«.

- Iztočnica alias je tako v SSKJ1 kot v SP2001 opredeljena kot prislov, v SSKJ2 je postala členek.

- Podiztočnica brezdvomno je v SSKJ1 in SP2001 prislov, v SSKJ2 je opredeljena kot členek. V nasprotju s tem je podiztočnica nedvomno opredeljena kot prislov s pojasnilom »v členkovni rabi«.

- Iztočnica čuda je v SSKJ1 in SP2001 prislov, v SSKJ2 je opredeljena kot členek.

- Iztočnica malce je v SSKJ1 in SP2001 prislov, v SSKJ2 je opredeljena kot členek.

- Iztočnica naj je v SSKJ1 členek, v SP2001 členek, v SSKJ2 je opredeljena kot členica.

- Iztočnica najmanj je v SSKJ1 prislov, v SP2001 členek, v SSKJ2 prislov »v členkovni rabi«.

- Iztočnica namreč je v SSKJ1 prislov, v SP2001 veznik, v SSKJ2 členek.

- Podiztočnica neutajljivo je v SSKJ1 in SP2001 prislov, v SSKJ2 je členek.

- V pomensko ustrezajočih geselskih člankih je iztočnica nič v SSKJ1 prislov, v SP2001 zaimek, v SSKJ2 členek.

Takih primerov je v celem slovarju ogromno in materija kliče po podrobnejši obravnavi. Tu smo lahko samo namignili na razsežnost problema. V osnovi pa lahko rečemo, da je SSKJ2 na ravni slovničnega opisa pri slovničnih besednih vrstah odprl pandorino (ali Pandorino) skrinjico, ki jo bo prej ali slej treba zapreti s konsistentnim opisom. Skratka, ta hip vsaj pri slovničnih ali funkcijskih besednih vrstah pravzaprav ne vemo, kaj je kaj.

\section{ZAKLJUČEK}

Skozi celotno analizo se ponuja vtis, da razen pri pravkar obravnavani slovnični tematiki, ki je po vsej verjetnosti delo dr. Andreje Žele, o čemer lahko sklepamo po vzporedni izdaji Slovarja slovenskih členkov (Žele 2014), pri drugi izdaji 
SSKJ gre za nekakšno vajo v slogu avtorske ekipe, namenjeno treningu za večji slovarski podvig. Kot vadbeni pripomoček za to vajo je bila uporabljena ali zlorabljena prva izdaja SSKJ, na sebi konsistenten in dober izdelek, ki pa bi ga bilo treba pustiti tam, kjer je bil - na častnem mestu opisa slovenščine večjega dela 20. stoletja. Domala ista avtorska ekipa je kot svoj prvi rezultat sproducirala SNB, ki verjetno precej bolje izraža duha te ekipe. Tudi ta slovar pa bi morali pustiti tam, kjer je bil - na mestu predragega, bistveno predolgo nastajajočega in "neknjižnega" posodobitvenega dodatka k SSKJ, ki ga je doletela usoda, da je zasnovan za papir pristal v svetu, ki pozna ali bo kmalu poznal samo še digitalno formo (Rundell 2014). Hkrati končni združeni izdelek ni prosto dostopen, kar je ob javnem financiranju svojevrsten absurd. To sicer ni tema tega prispevka, a bi si zaslužila vsaj pozornost financerjev in strokovne javnosti.

Če privzamemo, da je leksikografska ekipa želela na nečem vaditi, je največji problem stranski učinek te odločitve, ki je v taki konstelaciji nujen, tj. popolna tajnost in netransparentnost tako snovanja kot procesa in nazadnje rezultata. Precej se je bilo treba potruditi, da so v končnem besedilu povsem nevidne vse spremembe, ki bi bile lahko podvržene preverjanju. Tako kot je pri treningih običaj, je potekal v miru in tišini, brez vmešavanja javnosti ali prevzemanja odgovornosti, ki pritiče glavni tekmi. Od tod umanjkanje vsake izhodiščne javne razprave o drugi izdaji SSKJ, neobstoj kakršnegakoli koncepta, preverjanja začetnih rešitev in imenovanja odgovornih za ta podvig. SAZU v preteklosti ni delovala na tak način. Ker pred nastankom (strokovna) javnost ni izvedela nič o vsebini bodočega slovarja in je bila zato deležna toliko bolj agresivnega oglaševanja izdelka, je (bila) zato zdaj potrebna toliko natančnejša analiza, kaj se je v drugi izdaji pravzaprav zgodilo.

SAZU je izdelek post festum uradno blagoslovila s podpisom predsednika $\mathrm{v}$ kolofonu in govorom na uradni predstavitvi, verjetno vsem (ne)udeležencem kaj drugega tudi ni preostalo. Če je to novi akademski credo, se je treba vprašati, kam točno bomo z njim prišli, vsaj glede opisa slovenskega jezika. Eno pa je 
jasno - če se je druga izdaja SSKJ zgodila pod mentorstvom in idejnim vodenjem obeh starejših raziskovalcev, ki sta podpisana pod slovar, bi bilo od vseh višjih odgovornih precej neodgovorno, če bi ista odločevalca imela karkoli opraviti pri usodi novega slovarja, pri katerem bo treba precej bolje razmisliti, kako se jezik opisuje v digitalnem 21. stoletju. Temu odločevalskemu paru je treba prišteti še organ, ki odloča o vsebini inštitutskega dela - znanstveni svet, predvsem predsednika, ki je ta organ vodil v času nastajanja druge izdaje SSKJ. Po suhem treningu leksikografske ekipe, po katerem smo na suhem ostali vsi uporabniki slovarja, tako tisti, ki bi ga morali kupiti, a ga niso mogli, kot tisti, ki so ga, a bi bilo zaradi vsebine bolje, če ga ne bi, se bo treba leksikografije lotiti malo resneje.

\section{LITERATURA}

Ahlin, M., Lazar, B., Praznik, Z. in Snoj, J. (2014): Slovar slovenskega knjižnega jezika. Druga, dopolnjena in deloma prenovljena izdaja. Izdali Slovenska akademija znanosti in umetnosti, Znanstvenoraziskovalni inštitut Slovenske akademije znanosti in umetnosti, Inštitut za slovenski jezik Frana Ramovša. Jezik in slovstvo, 59 (4): 121-127.

Bajec, A., Kolarič, R. in Rupel, M. (1956): Slovenska slovnica. Ljubljana: Državna založba Slovenije.

Besedišče slovenskega jezika z oblikoslovnimi podatki: po gradivu za slovar sodobnega knjižnega jezika zbrane besede, ki niso bile sprejete $v$ Slovar slovenskega knjižnega jezika (1998). Ivanka Šircelj-Žnidaršič (ur.). Ljubljana: Znanstvenoraziskovalni center SAZU, Založba ZRC.

Dobrovoljc, H. in Bizjak Končar, A. (2011): Vprašanja obvestilnosti sodobnega pravopisnega slovarja. V M. Jesenšek (ur.): Izzivi sodobnega slovenskega slovaropisja: 86-109. Maribor: Mednarodna založba Oddelka za slovanske jezike in književnosti, Filozofska fakulteta.

Dobrovoljc, H. (2004): Pravopisje na Slovenskem. Ljubljana: Založba ZRC, 


\section{ZRC SAZU.}

Gantar, P. (2014): Moč in nemoč korpusnega pristopa k analizi pomenov. V S. Bergoč in I. Grahek (ur.): Novi slovar za 21. stoletje: E-zbornik prispevkov s Posveta o novem slovarju slovenskega jezika na Ministrstvu za kulturo 12. 2. 2014, Ljubljana, april 2014: 14 str. Ljubljana: Ministrstvo za kulturo.

Gigafida. Dostopno prek: http://www.gigafida.net (25. 12. 2014).

Gorjanc, V. (2014): O heteronormativnosti slovarskega opisa slovenskega jezika: homoseksualnost, ekshibicionizem in druge perverznosti. Narobe, 7 (27/28): 12-15.

Gorjanc, V. (2001): Jezikovni viri kot osnova jezikovnega opisa. V A. Vidovič Muha (ur.): Slovenski knjižni jezik - aktualna vprašanja in zgodovinske izkušnje : ob 45o-letnici izida prve slovenske knjige : povzetki predavanj = The standard Slovene language - topical issues and historical experience : on the occasion of the 45oth anniversary of the publication of the first Slovene book : summaries = Slovenskij literaturnyj jazyk - aktual'nye voprosy i istoričeskij opyt : $k$ 45o-letiju izdanija pervoj slovenskoj knigi : rezjume dokladov, Ljubljana, 5.-7. december 2001: 20. Ljubljana: Filozofska fakulteta, Oddelek za slovanske jezike in književnosti, Center za slovenščino kot drugi/tuji jezik.

Gliha Komac, N., Jakop, N., Kern, B., Klemenčič, S., Krvina, D., Ledinek, N., Michelizza, M., Mirtič, T., Perdih, A., Petric, Š., Snoj, M. in Žele, A. (2014): Izbrisani slovarski sestavki iz druge, dopolnjene in deloma prenovljene izdaje Slovarja slovenskega knjižnega jezika. Jezikoslovni zapiski, 20 (1): 235.

Logar, N. (2014): Verodostojnost korpusov kot gradivnega vira za slovar. V S. Bergoč in I. Grahek (ur.): Novi slovar za 21. stoletje: E-zbornik 
prispevkov s Posveta o novem slovarju slovenskega jezika na Ministrstvu za kulturo 12. 2. 2014, Ljubljana: 13 str. Ljubljana: Ministrstvo za kulturo.

Logar, N. (2009): O dveh znanstvenomonografskih leksikalnih seznamih. Alenka Gložančev, Primož Jakopin, Mija Michelizza, Lučka Uršič, Andreja Žele: Novejša slovenska leksika (v povezavi s spletnimi jezikovnimi viri). Ljubljana: Založba ZRC, ZRC SAZU, 2009. 408 str. Jezik in slovstvo, 54 (3-4): 153-159.

Müller, J. (2009): Kritične misli in zamisli o SSKJ. V A. Perdih (ur.): Strokovni posvet o novem slovarju slovenskega jezika, 23. in 24. oktober 20o8: 17-25. Ljubljana: Založba ZRC, ZRC SAZU.

Rozman, T. (2010): Vloga enojezičnega razlagalnega slovarja slovenščine pri razvoju jezikovne zmožnosti: doktorska disertacija. Mentor Vojko Gorjanc. Ljubljana: Filozofska fakulteta.

Rundell, M. (2014): Macmillan English Dictionary: The End of Print? Slovenščina 2.0, 2 (2): 1-14.

Slovar novejšega besedja slovenskega jezika (2012/spletna različica: 2014). Ljubljana: ZRC SAZU. Dostopno prek: http://www.fran.si (25. 12. 2014). Slovar slovenskega knjižnega jezika: poskusni snopič (1964). Anton Bajec idr. (ur.). Ljubljana: Slovenska akademija znanosti in umetnosti.

Slovar slovenskega knjižnega jezika (1970-1991/spletna različica: 2014).

Ljubljana: ZRC SAZU. Dostopno prek: http://www.fran.si (25. 12. 2014).

Slovar slovenskega knjižnega jezika: druga izdaja (2014/spletna različica: 2014). Ljubljana: ZRC SAZU. Dostopno prek: http://www.sskj2.si (25. 12. 2014).

Slovenski pravopis (2001/spletna različica: 2014). Ljubljana: ZRC SAZU. Dostopno prek: http://www.fran.si (25. 12. 2014). 
Toporišič, J. idr. (2001): Slovenski pravopis. Ljubljana: Založba ZRC.

Toporišič, J. (200o): Slovenska slovnica. Maribor: Založba Obzorja.

Toporišič, J. (1994): Teoretična podstava slovarja novega SP. Slavistična revija, 42 (4): 455-473.

Toporišič, J. (1976): Slovenska slovnica. Maribor: Založba Obzorja.

Žele, A. (2014): Slovar slovenskih členkov. Ljubljana: Založba ZRC. 


\section{A COMPARISON OF THE FIRST AND SECOND EDITIONS OF THE DICTIONARY OF LITERARY SLOVENE}

The paper investigates the differences between the first and second editions of the Dictionary of Literary Slovene (SSKJ). The analysis is two-fold: first, a detailed comparison of headword lists of both editions is conducted, followed by the comparison of 2,500 entries from both editions, consisting of a hundred entries for each letter. The analysis shows that the spelling and pronunciation changes to the entries in the second edition were made without the approval of any relevant language authority. Also, the changes introduced are random and inconsistent, and are affecting the consistency of lexicographic description of the first edition, especially on the grammatical level. Furthermore, the editorial decision to make identifying the source of lexicographic information (i.e. the first edition of SSKJ or the Dictionary of New Words of the Slovenian language) impossible, raises doubts about lexicographic credibility of the second edition as a description of contemporary Slovene. From the lexicographic perspective, it would have been more appropriate to leave the first edition unchanged and the Dictionary of New Words of the Slovenian language as a separate publication. In addition, the second edition of SSKJ is not freely available online, and neither of the editions is freely available in the form of a dictionary database for natural language processing and other uses.

Keywords: the Dictionary of Literary Slovene, the Dictionary of New Words of the Slovenian language, Slovenian Orthography 
To delo je ponujeno pod licenco Creative Commons: Priznanje avtorstvaDeljenje pod enakimi pogoji 2.5 Slovenija.

This work is licensed under the Creative Commons Attribution ShareAlike 2.5 License Slovenia.

http://creativecommons.org/licenses/by-sa/2.5/si/

(C) (1) () 